\title{
Investigation of Hydrokinetic Properties of Hydrogeologic Units of Sandy Lithofacies: A Case Study of Parts of Enugu State, Southeastern Nigeria
}

Johnson Cletus Ibuot ( $\sim$ johnson.ibuot@unn.edu.ng )

University of Nigeria, Nsukka

Emmanuel T. Omeje

University of Nigeria

Daniel Nnemeka Obiora

University of Nigeria

\section{Research}

Keywords: Hydrokinetic, Aquifer, Hydraulic, permeability, tortuosity

Posted Date: October 27th, 2020

DOI: https://doi.org/10.21203/rs.3.rs-95693/v1

License: (c) (i) This work is licensed under a Creative Commons Attribution 4.0 International License.

Read Full License 
Investigation of hydrokinetic properties of hydrogeologic units of sandy lithofacies: a case study of parts of Enugu State, Southeastern Nigeria

Emmanuel T. Omeje, Johnson Cletus Ibuot*, and Daniel Nnemeka Obiora

Department of Physics and Astronomy, University of Nigeria, Nsukka

Corresponding author email: johnson.ibuot@unn.edu.ng 


\begin{abstract}
Vertical electrical sounding employing schlumberger electrode configuration was carried out in thirty locations across some parts of Enugu state, to investigate the hydrokinetic properties of hydrogeologic units of the study area. The result shows that resistivity and thickness of aquifer ranges from 27.3 to $59569.0 \Omega \mathrm{m}$ and 23.3 to $242.1 \mathrm{~m}$ respectively. Permeability and fractional porosity values range from 4531.254 to $74006.76 \mathrm{mD}$ and 0.026 to 0.159 . AQI having a mean value of $13.5451 \mu \mathrm{m}$ range from 6.809 to $52.976 \mu \mathrm{m}$. FZI and HFU values range from 37.582 to 1962.074 $\mu \mathrm{m}$ and 18 to 26 respectively. Contour maps were generated from the results to visualize the variations of the hydrokinetic properties across the study area. From the contour maps, southern part of the study area was identified to be characterized with high AQI, FZI and HFU with northwestern part and a small proportion along the southwestern part identified as areas with low AQI, FZI and HFU. HFU along the study area was observed to be fractionated into nine distinct properties (HFU 18, HFU 19, HFU 20, HFU 21, HFU 22, HFU 23, HFU 24, HFU 25, and HFU 26) with HFU 19 and HFU 20 dominating the area. The results from the nine hydraulic flow units based on flow zone indicator cut off values (Log FZI $>0.25)$ shows that the reservoir quality is very high.
\end{abstract}

Key words: Hydrokinetic, Aquifer, Hydraulic, permeability, tortuosity, 


\section{Introduction}

Water is an essential demand of life and can be of a great challenge when its extraction/exploitation is carried out without any geophysical knowledge about the area. Groundwater moves underground through the interconnected pores of rocks and soil, and stored in underground layer of water-bearing permeable rock, rock fractures or unconsolidated materials such as gravel, sand, or silt. Hydrofacies analysis of aquifer repositories can be employed to study the distribution of pore properties and aquifer quality. Complex variation comprehension in pore geometry having different lithofacies is a tool to advanced aquifer description and extraction. Aquifer architecture and quality is controlled by several factors which include the hydrokinetic properties. Sedimentary facies and diagenesis controls the porosity and permeability distribution in hydrogeologic units (Schlager 2005). Groundwater which is usually located within weathered, fractured or faulted chambers of rock units has its occurrence, flow and storagibility in a rock terrain influenced by the geologic processes. As subsurface density increases, porosity decreases with depth due to pressure which increases with depth (George et al., 2016). These geologic processes cause a change in the permeability, aquifer quality index, flow zone, and hydraulic flow unit which are the hydrokinetic properties that act as dependents factors and indicators for the characterization and discharge of groundwater. Hydrokinetic properties are consistent properties that control fluid flow and enable segmenting of aquifer into different distinctive/unique geophysical class. It also gives a distinction between geologic units having similar pore features. These distinctive properties tend to produce excellent aquifer characterization through classification of aquifer units into hydraulic flow units (George 2020). The knowledge of permeability and porosity helps in understanding the hydrokinetic properties of hydrogeologic units. In groundwater repositories, the quality of groundwater is dependent on 
the efficiency of the flow unit and the contamination indices present in the unit (Abd-Elhamid and Javidi 2011; Basack et al. 2014). Accustomed examination and management of groundwater are extremely requisite as a result of possible contamination which can be controlled by the hydrokinetic properties and geologic settings (Rao and Screenivasulu 2004).

Electric resistivity method is a geophysical method that contributes significantly to groundwater exploration and exploitation, especially when pumping test is not affordable. Information realized from interpreted resistivity data gives a better understanding of the aquifer system. This work employed indirect electrical resistivity technique in order to investigate and characterize the hydrokinetic properties of hydrogeologic units of sandy lithofacies.

\section{Location and Geological setting of the Study Area}

The study area covers Nsukka, Igbo-Eze south and Udi local government areas of Enugu state and lies within the Anambra sedimentary basin in Nigeria. The study area is characterized by dry and wet seasons within the tropical rain forest/Guinea savannah belt of Nigeria. Nsukka Formation and the underlying Ajali Sandstone underlies the study area, the Ajali Sandstone is a thick friable, poorly sorted, and coarse-medium grained cross-bedded sandstone of Maastrichtian age. Outcrops are seen in deep gullies incised along the lower slopes of an escarpment that run across the area from north to south separating two major drainage basins-the Cross river on the east and the Anambra on the west. Ajali Sandstone is underlain by the Mamu Formation (Lower Coal Measures) Campano-Maastrichtian age though outcrops of this formation are seen at the boundary of the Ajali Formation and Mamu Formation on the escarpment away from the study area. Also, the underlying Enugu shale is usually faced with seasonal fluctuations with little or no supply during the dry seasons as a result of the poor hydrologic nature of the shale. The shale group is massive and highly jointed with sets of vertical joints. It is generally not porous or 
permeable, but the formation could yield water to boreholes if fractured, the fractured nature makes it a potential aquifer repository. Also found in the study area are the residual hills and dry valleys, which are related to the rock type or geologic formation underlying the area (Stow 2005). Surface water body that traverse the area emanates from the contact between the bottom of the Ajali Formation and the upper part of Mamu Formation at the foot of the scarp. Dry valleys and residual hills also characterises the study area as the prime landforms. These two major geomorphic structures are the resultant effect of weathering and differential erosion of clastic materials which are remnant of Nsukka Formation.

\section{Materials and methods}

Estimating the hydrokinetic properties of different geologic unit in the study area were achieved through the data acquired from thirty vertical electrical sounding points using Schlumberger electrode configuration with the aid of 'SSR-MP-ATS' Resistivity Meter. Potential fields of current sent into the ground through one pair of electrode each corresponding to potential and current electrode were measured. Extensible current electrode (AB) and potential electrode $(\mathrm{MN})$ separation of $900 \mathrm{~m}$ and $40 \mathrm{~m}$ respectively were achieved by considering accessible roads in locating areas for VES points. For quality assurance in the field measurements, the separation between the potential electrodes was one fifth of the current electrode separations (George et al. 2016a). $\mathrm{MN}$ varied from $0.5 \mathrm{~m}$ at $\mathrm{AB}=2 \mathrm{~m}$ up to $40 \mathrm{~m}$ at $\mathrm{AB}=900 \mathrm{~m}$ (Akpan et al. 2013). During field plating two third of the each electrode length perforated the subsurface. Apparent resistance $\left(R_{a}\right)$ as measured from the field data were vehicle to computing apparent resistivity ( $\left.\square_{\mathrm{a}}\right)$ values shown in equation (1); 
$\rho_{a}=\pi\left[\frac{\left(\frac{A B}{2}\right)^{2}-\left(\frac{M N}{2}\right)^{2}}{M N}\right] R_{a}=K \cdot R_{a}$

Where $\pi\left[\frac{\left(\frac{A B}{2}\right)^{2}-\left(\frac{M N}{2}\right)^{2}}{M N}\right]=K$ is geometric factor, it depends on the electrode configuration.

Field data geologic model were obtained Following Akpan et al., 2009. Plots of apparent resistivity against half current electrode spacing on a bi-logarithmic graph were carried out to achieve the manual modeling. Outliers at cross over points were deleted or readings averaged in order to extract Lateral in-homogeneities from curves produced. (Chakravarthietal, 2007; Akpan et al., 2006). The bi-logarithmic graph were refined using computer based VES modeling software program called WINRESIST which generates geoelectric sounding curves in the process and classify the curves into layers with different resistivity, depth and thickness (Fig. 1). 


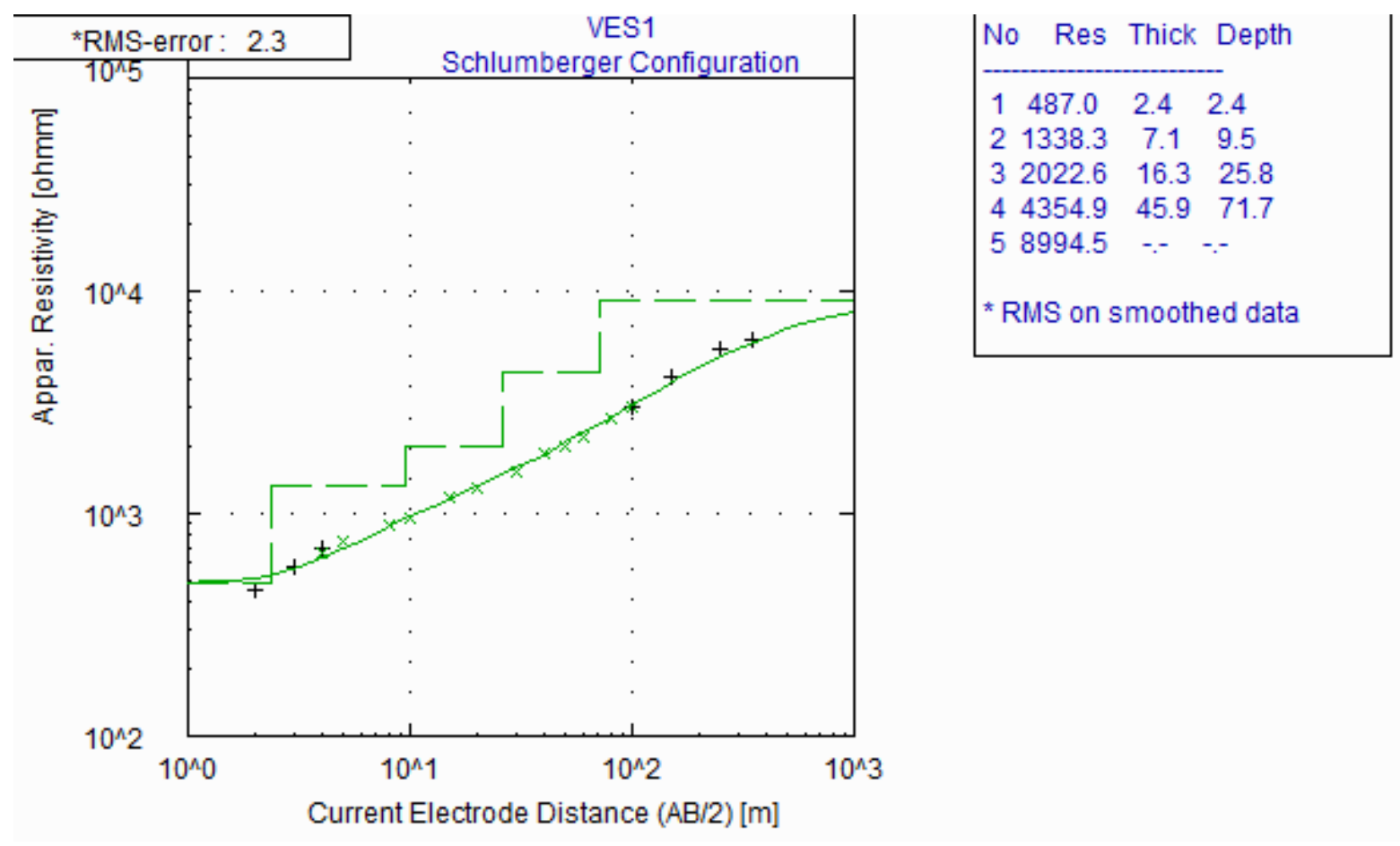

Fig. 1: VES curve showing VES1 resistivity, thickness and Depth

In an attempt to identify the hydrokinetic properties (aquifer quality index, flow zone indicator and hydraulic flow unit) of the geologic units $(G U)$ of the study area, hydrodynamic properties such as permeability, porosity and normalized porosity index were first estimated. Fig. 2 illustrate a flow chart showing the research methodology. 
Fig 2: Flow chart showing research methodology 
Permeability values were estimated following Kozeny (1927) and Carmen (1937) generalized equation which was derived by the combination of Darcy's law for flow in a porous medium and Poiseuille's law for flow in a tube as shown in equation 4.

$$
\begin{aligned}
& K=\frac{\phi r}{8 \tau^{2}}=\frac{\phi}{2 \tau^{2}}\left(\frac{r}{2}\right)^{2}=\frac{\phi r_{m}{ }^{2}}{2 \tau^{2}} \\
& S_{g v}=\frac{1}{r_{m}}\left(\frac{\phi}{1-\phi}\right)=\frac{1}{r_{m}} * P H I N
\end{aligned}
$$

Combining equations 2 and 3 produces the generalized Kozeny and Carmen equation in equation 4.

$$
K=\frac{\phi^{3}}{\left(-\phi_{-}^{2}\right.}\left(\frac{1}{2 \tau^{2} S_{g v}{ }^{2}}\right)=\operatorname{PHIN}_{-}^{\boldsymbol{z}} * \phi^{*}\left(\frac{1}{F_{s} \tau^{2} S_{g v}{ }^{2}}\right)
$$

$K$ is permeability, $\phi$ is effective fractional porosity, $r_{m}$ is mean hydraulic radius, $F_{s}$ is shape factor and it is equals 2 for a circular cylinder, $\tau$ is tortuosity, $S_{g v}$ is surface area per pore volume while PHIN is normalized porosity index. $F_{s} \tau^{2} S_{g v}$ is a function of the geologic properties of the porous medium as it varies with changes in the pore geometry. Porosity values of the $G U$ of area were estimated with the knowledge of the water-bearing hydraulic conductivity of the area as shown in equation 5.

$$
\phi=25.5+4.5 \operatorname{In} K_{h}
$$

Hydraulic conductivity values were estimated following Heigold et al. 1979 equation as shown

$$
K_{h}=\frac{386.40}{R_{w}^{0.93283}}
$$


Formation resistivity factor and tortuosity values were estimated following Humbles equation and TNO (1976) equation respectively as shown in equation 7 and 8

$$
\begin{gathered}
F=\frac{0.62}{\phi^{2.15}} \\
\tau=\sqrt{F \phi}
\end{gathered}
$$

The hydraulic radius values were estimated according to George et al (2018) equation shown in equation 9

$$
r=\sqrt{\frac{0.52 * \mu_{d} * K_{h} * \tau}{\delta_{w} * g * \phi}}
$$

Aquifer quality Index method presented a robust and reliable methodology for enhanced reservoir description which also captures the pore-body/throat attributes of a given aquifer system. The methodology as introduced by Amaefule et al. (1993), is based on a modified Kozeny (1927) and Carmen (1937) relationship. Each distinguished flow unit has a characteristic value of aquifer quality index. The aquifer quality index (AQI) concept is a unique and useful way to quantify the flow character of an aquifer through the use of the flow zone indicator (FZI).

$$
A Q I=\pi * 10^{-2} * \sqrt{\frac{K}{\phi}}
$$

The FZI offers a relationship between geophysical properties on a large scale such as wellbore level. The flow zone indicator which is controlled by the geophysical properties of the environment, was calculated using equation 11

$$
F Z I=\frac{A Q I}{P H I N}
$$


The flow zone model can be converted to 3D discrete rock type which was employed in calculating the hydraulic flow unit according to George (2020)

$$
H F U=\operatorname{round} * \ln (F Z I)+10.6^{-}
$$

The key to a better aquifer characterization and exploitation emanates with the understanding of the differences in pore geometry within various lithofacies. These differences gave rise to a further subdivision known as flow units. Hydraulic flow unit according to Tiab(2004) is a continuous body over a specific aquifer volume that practically possess consistent geophysical and fluid properties which uniquely characterize its static and dynamic communication with the wellbore. A hydraulic flow unit (HFU) is a representative volume or section of an aquifer. It can also be described as a section of the reservoir rock volume within which the pore throat characteristics of porous media regulating the fluid flow are unique and predictably different from the rest of the reservoir (Amaefule et al., 1993; Porras and Campos, 2001). Each HFU, has a distinct geologic (sedimentary structure and texture) and geophysical (permeability and porosity) properties from properties of other section of the aquifer. Zonation of Hydraulic flow unit can be through Lorenz plot or the application of flow zone indicator. This work employed FZI method as proposed by Amaefule et al. (1993) in determining the HFU of the aquifer in the study area.

\section{Results and Discusion}

The magnitude of the aquifer layer resistivity and thickness as shown in Table 1, range from 27.3 to $59569.0 \Omega \mathrm{m}$ and 23.3 to $242.1 \mathrm{~m}$ respectively. This range of values signifies the existence of low to high resistive geomaterial in the aquifer layer. Estimate of the hydrokinetic properties of the hydrogeologic units were obtained from these range of values. Spatial variability of these properties were visualize through graphs and contour maps. The variability of these properties is 
essential in prognosis of dynamic characteristics of aquifer used in groundwater flow monitoring and management (Rao and Sreenivasulu 2004). Permeability $\left(K_{p}\right)$ in $(\mu \mathrm{m})^{2}$ were changed to millidarcy $(\mathrm{mD})$ by dividing $\mathrm{K}_{\mathrm{p}}$ in $(\mu \mathrm{m})^{2}$ with a conversion factor given as $0.0009869233(\mu \mathrm{m})^{2}$ and the results presented in Table 1. Porosity and permeability are key parameters that influence the flow in aquifer units and are spatially distributed across the study area. Fig. 3 shows that greater proportion of southern parts of the study area are characterized with high permeability distribution having range $\geq 40000$, with northern parts and a small fraction along the southwestern part characterized with low permeability distribution. Fig. 4 shows greater part of the study area as dominated with low Porosity distribution having range $\leq 0.05$ with small portions in both the northwestern and southwestern part characterized with high porosity. This show that greater parts of the southern zone which are well permeable are not highly porous and the northwestern part which are highly porous are not well permeable suggesting a poor interconnectivity of pores along the northwestern zone and the presence of clay in the aquifer. The discrepancy in pore system characteristics may be as a result of diagenetic and depositional characteristics (Jodeyri-Agaii et al 2018). The high permeability distribution observed along the southern part of the study area despite low porosity can also be as a result of open and enlarged fractures in the geologic unit of the considered area. This explains the fact that porosity is not the only parameter upon which permeability variation can be explained. Due to high permeability in the southern zone, it can be deduced that shale to sand ratio is appreciably low in the aquifer unit formation (George, 2020). 


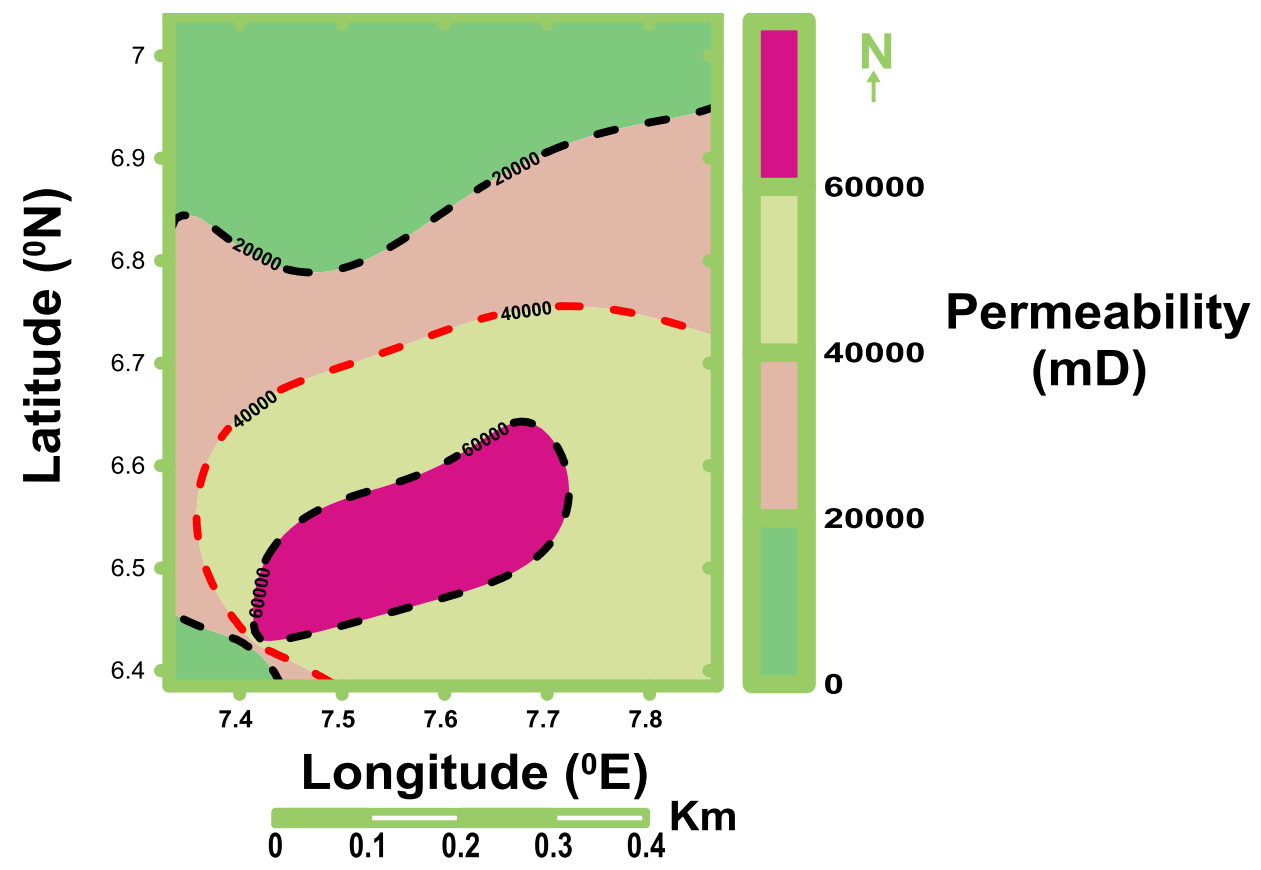

Fig. 3: Contour map showing Permeability variation

Permeability variation can also be linked to existence of more than one flow unit in an aquifer where each layer has distinct fluid flow properties. A fractional porosity- permeability relation for the study area was obtained as shown in Figure 5. Fractional porosity has an inverse functional power relation with permeability (in $\mathrm{mD}$ ) having coefficient of determination $\mathrm{R}^{2}=$ 0.641.Fractional porosity translation to permeability for groundwater reservoir in the study area is as show given in equation 13. The power relation in equation 13 suggests that permeability $(\mathrm{mD})$ in this study area is not wholly influenced by fractional porosity. 
1 Table 1: Summary of results of hydrokinetic properties of hydrogeologic units

\begin{tabular}{|c|c|c|c|c|c|c|c|c|c|c|c|c|c|c|c|c|}
\hline $\begin{array}{l}\text { VES } \\
\text { Stations }\end{array}$ & $\begin{array}{l}\text { Long. } \\
\left({ }^{\mathbf{O}} \mathbf{E}\right)\end{array}$ & $\begin{array}{l}\text { Lat. } \\
\left({ }^{\mathbf{O}} \mathbf{N}\right)\end{array}$ & $\rho_{\mathrm{a}}(\Omega \mathrm{m})$ & $\mathbf{h}_{\mathbf{a}}(\mathbf{m})$ & $\begin{array}{l}K_{h} \\
\text { (m/day) }\end{array}$ & $\phi$ & PHIN & $\mathbf{F}$ & $\tau$ & $\begin{array}{l}\text { RPI } \\
(m)\end{array}$ & $\begin{array}{l}\text { SPV } \\
\left(m^{-1}\right)\end{array}$ & $\begin{array}{l}\mathbf{K}_{\mathbf{P}} \\
\mathrm{s} / \mathrm{m}^{\mathrm{z}}\end{array}$ & $\begin{array}{l}\mathbf{K}_{\mathbf{P}} \\
(m D)\end{array}$ & $\begin{array}{l}\mathbf{A Q I} \\
\mathrm{S} \mathrm{m}_{-}^{-}\end{array}$ & $\begin{array}{l}\text { FZI } \\
\mathrm{s}_{-}-\end{array}$ & HFU \\
\hline 1 & 7.410 & 6.400 & 4354.9 & 45.9 & 0.156 & 0.058 & 0.062 & 282.502 & 4.048 & 0.00089 & 1123.222 & 5.392 & 5463.444 & 9.637 & 155.435 & 21 \\
\hline 2 & 7.414 & 6.405 & 9954.7 & 104.7 & 0.072 & 0.073 & 0.079 & 172.285 & 3.546 & 0.000505 & 1981.801 & 4.613 & 4674.122 & 7.945 & 100.57 & 20 \\
\hline 3 & 7.418 & 6.400 & 11336.2 & 58.1 & 0.064 & 0.076 & 0.082 & 157.995 & 3.465 & 0.000461 & 2169.699 & 4.521 & 4580.903 & 7.709 & 94.012 & 20 \\
\hline 4 & 7.413 & 6.415 & 5214.6 & 80.5 & 0.132 & 0.061 & 0.065 & 253.473 & 3.932 & 0.000787 & 1270.59 & 5.163 & 5231.41 & 9.195 & 141.462 & 21 \\
\hline 5 & 7.397 & 6.393 & 5495.6 & 72.8 & 0.125 & 0.062 & 0.066 & 244.765 & 3.896 & 0.000756 & 1322.409 & 5.087 & 5154.403 & 9.054 & 137.182 & 20 \\
\hline 6 & 7.402 & 6.385 & 11724.2 & 23.3 & 0.062 & 0.077 & 0.083 & 153.616 & 3.439 & 0.000449 & 2227.244 & 4.521 & 4580.903 & 7.659 & 92.277 & 20 \\
\hline 7 & 7.403 & 6.409 & 20445.6 & 134.4 & $\mathbf{0 . 0 3 7}$ & 0.094 & 0.104 & 100.038 & 3.067 & 0.000296 & 3373.188 & 4.75 & 4812.937 & 7.105 & 68.317 & 19 \\
\hline 8 & 7.399 & 6.422 & 41342.5 & 158.5 & 0.019 & 0.13 & 0.149 & 49.821 & 2.545 & 0.000165 & 6076.945 & 6.033 & 6112.937 & 6.809 & 45.698 & 18 \\
\hline 9 & 7.422 & 6.434 & 27.3 & 24.0 & 17.674 & 0.026 & 0.027 & 1585.62 & 6.421 & 0.017826 & 56.099 & 73.039 & 74006.76 & 52.976 & 1962.074 & 26 \\
\hline 10 & 7.443 & 6.885 & 913.3 & 66.6 & 0.669 & 0.042 & 0.044 & 565.465 & 4.873 & 0.002377 & 420.676 & 9.675 & 9803.193 & 15.17 & 344.773 & 22 \\
\hline 11 & 7.339 & 6.847 & 230.9 & 73.9 & 2.412 & 0.034 & 0.035 & 890.66 & 5.503 & 0.005331 & 187.579 & 19.544 & 19802.96 & 23.964 & 684.686 & 24 \\
\hline 12 & 7.482 & 6.901 & 22142.5 & 69.7 & 0.034 & 0.097 & 0.107 & 93.504 & 3.012 & 0.000277 & 3607.059 & 4.704 & 4766.328 & 6.96 & 65.047 & 19 \\
\hline 13 & 7.482 & 6.842 & 59569.0 & 242.1 & 0.014 & 0.159 & 0.189 & 32.314 & 2.267 & 0.000121 & 8295.51 & 8.03 & 8136.397 & 7.103 & 37.582 & 18 \\
\hline 14 & 7.468 & 6.817 & 437.0 & 36.9 & 1.33 & 0.037 & 0.038 & 742.605 & 5.242 & 0.003704 & 269.998 & 13.336 & 13512.7 & 18.976 & 499.368 & 23 \\
\hline 15 & 7.47 & 6.998 & 12226.0 & 181.7 & 0.059 & 0.078 & 0.085 & 149.413 & 3.414 & 0.000434 & 2306.343 & 4.545 & 4605.221 & 7.63 & 89.765 & 20 \\
\hline 16 & 7.477 & 6.992 & 14004.6 & 119.3 & 0.052 & 0.082 & 0.089 & 134.181 & 3.317 & 0.000391 & 2555.447 & 4.52 & 4579.89 & 7.421 & 83.382 & 19 \\
\hline 17 & 7.487 & 6.997 & $\begin{array}{l}528.1 \\
\end{array}$ & 93.9 & 0.093 & 0.068 & $\mathbf{0 . 0 7 3}$ & 200.677 & 3.694 & 0.000606 & 1648.917 & 4.884 & 4948.713 & 8.471 & 116.041 & 20 \\
\hline 18 & 7.507 & 7.009 & 3745.4 & 57.3 & 0.179 & 0.056 & 0.059 & 304.64 & 4.13 & 0.00098 & 1020.063 & 5.492 & 5564.769 & 9.898 & 167.763 & 21 \\
\hline 19 & 7.458 & 6.997 & 14180.5 & 140.3 & 0.052 & 0.082 & 0.089 & 134.181 & 3.317 & 0.000391 & 2555.447 & 4.52 & 4579.89 & 7.421 & 83.382 & 19 \\
\hline 20 & 7.461 & 7.012 & 13880.1 & 130.9 & 0.053 & 0.081 & 0.088 & 137.768 & 3.341 & 0.000399 & 2506.69 & 4.472 & 4531.254 & 7.427 & 84.398 & 19 \\
\hline 21 & 7.462 & 7.007 & 1836.4 & 63.6 & 0.349 & 0.048 & 0.05 & 424.349 & 4.513 & 0.001546 & 647.008 & 7.037 & 7130.24 & 12.102 & 242.04 & 22 \\
\hline 22 & 7.470 & 7.035 & 10247.2 & 144.3 & 0.07 & 0.074 & 0.08 & 167.318 & 3.519 & 0.000492 & 2031.382 & 4.634 & 4695.4 & 7.91 & 98.875 & 20 \\
\hline 23 & 7.480 & 7.039 & 14634.9 & 136.3 & 0.05 & 0.083 & 0.091 & 130.73 & 3.294 & 0.00038 & 2631.035 & 4.575 & 4635.619 & 7.421 & 81.549 & 19 \\
\hline 24 & 7.331 & 6.874 & 25777.5 & 107.4 & 0.03 & 0.103 & 0.115 & 82.185 & 2.909 & 0.000248 & 4026.433 & 4.964 & 5029.773 & 6.939 & 60.339 & 19 \\
\hline 25 & 7.336 & 6.872 & 10926.8 & 32.8 & 0.066 & 0.075 & 0.081 & 162.559 & 3.492 & 0.000473 & 2114.248 & 4.514 & 4573.81 & 7.754 & 95.728 & 20 \\
\hline 26 & 7.677 & 6.630 & 36.3 & 29.0 & 13.549 & 0.027 & 0.028 & 1462.041 & 6.283 & 0.01515 & 66.005 & 61.541 & 62356.42 & 47.719 & 1704.25 & 25 \\
\hline 27 & 7.866 & 6.875 & 175.3 & 160.1 & 3.119 & 0.033 & 0.034 & 949.701 & 5.598 & 0.006206 & 161.127 & 23.444 & 23754.63 & 26.641 & 783.559 & 24 \\
\hline 28 & 7.353 & 6.863 & 360.3 & 112.3 & 1.593 & 0.036 & 0.037 & 787.665 & 5.325 & 0.004142 & 241.445 & 14.907 & 15104.52 & 20.339 & 549.703 & 23 \\
\hline 29 & 7.357 & 6.853 & 248.7 & 57.2 & 2.25 & 0.034 & 0.035 & 890.66 & 5.503 & 0.005149 & 194.215 & 18.231 & 18472.56 & 23.145 & 661.286 & 24 \\
\hline 30 & 7.331 & 6.874 & 10480.5 & 30.3 & 0.069 & 0.074 & 0.08 & 167.318 & 3.519 & 0.000489 & 2046.049 & 4.568 & 4628.526 & 7.853 & 98.163 & 20 \\
\hline
\end{tabular}




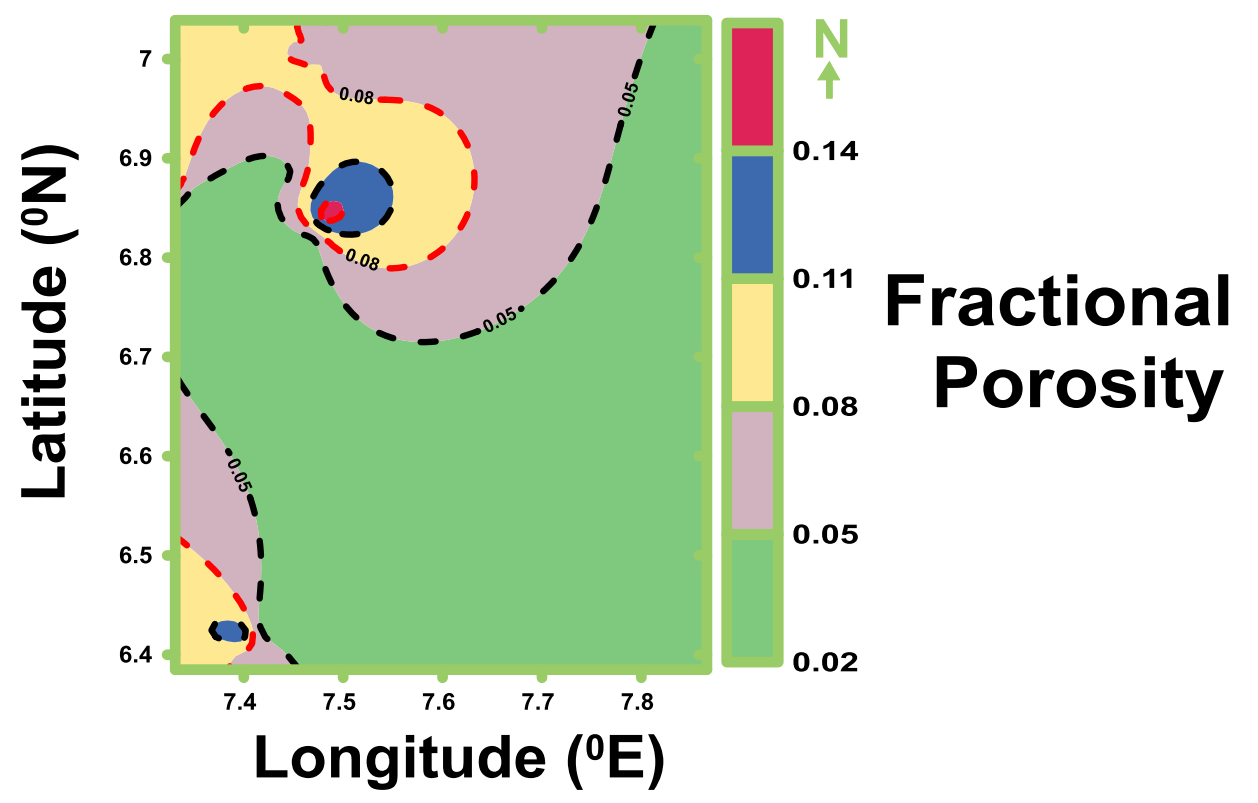

$\begin{array}{lllllll}4 & \mathrm{~s} & 0 & 0.1 & 0.2 & 0.3 & 0.4\end{array}$

$5 \quad$ Fig. 4: Contour map showing Fractional porosity variation

6 Fractional porosity translation to permeability for groundwater reservoir in the study area is as

7 show given in equation 13 . The power relation in equation 13 suggests that permeability $(\mathrm{mD})$ in

8 this study area is not wholly controlled by fractional porosity.

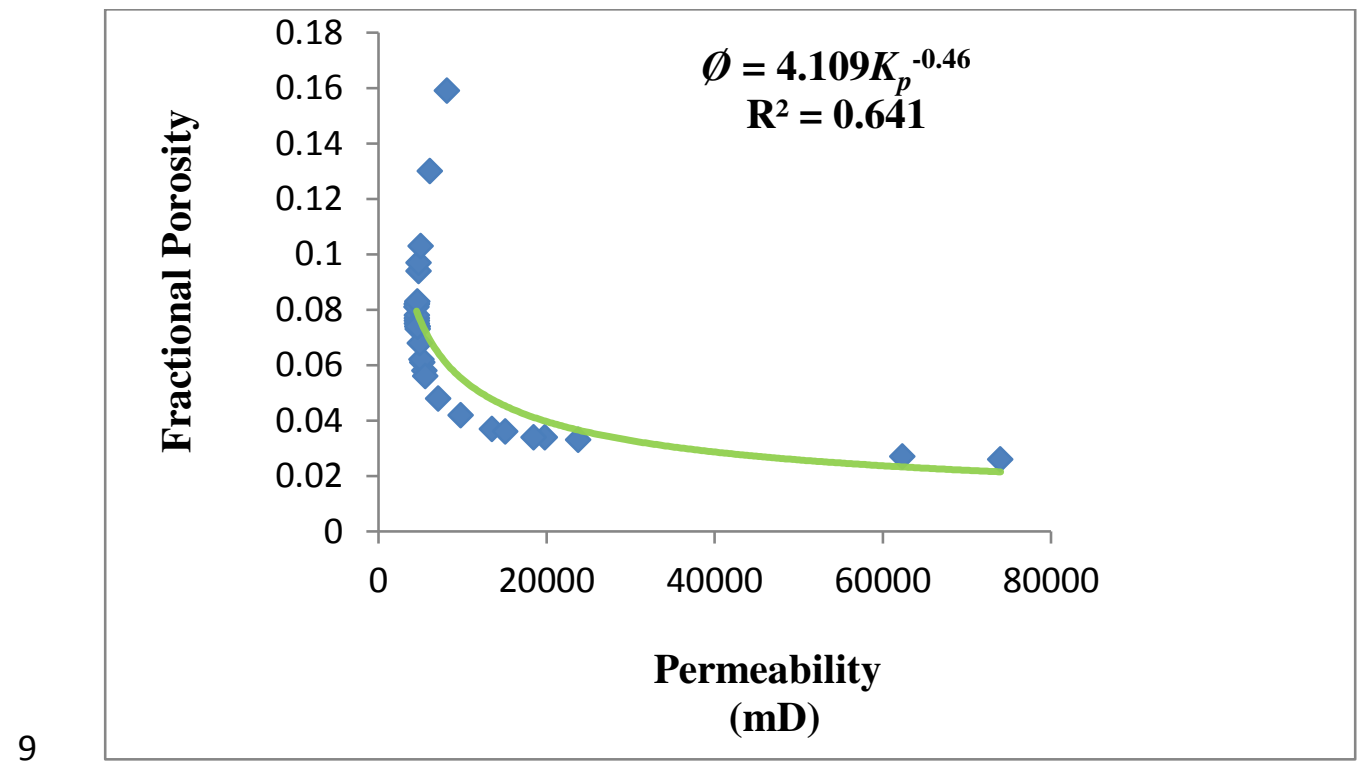

10

Fig. 5: Graph of porosity against permeability 
$11 \phi=4.109 k_{p}^{-0.46}$

12 Tortuosity values range from 2.267 to 6.421 having an average value of 4.013 . Greater part of

13 the study area is characterized with high tortousity distribution $(\tau \geq 4.9)$. The northwestern part

14 and small portion in the southwestern part are dominated with low tortuosity distribution as show

15 in Fig. 6 This shows a possible difficulty in groundwater transmissibility along the southern and

16 parts of the northeastern zones as compared to other zones in the study area.

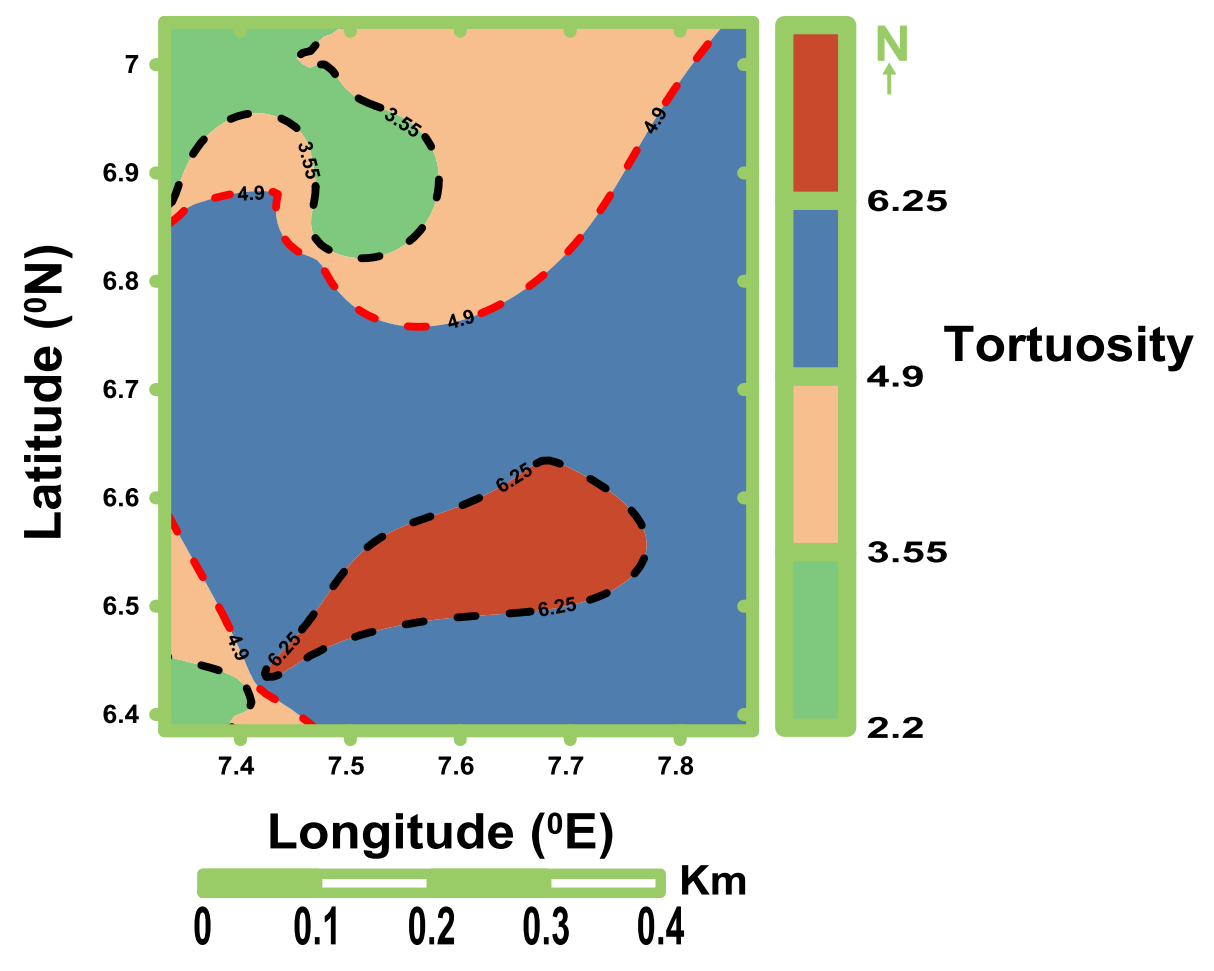

18 Fig. 6: Contour map showing Tortuosity variation

19 AQI range from 6.809 to $52.976 \mu \mathrm{m}$ with an average value of $13.5451 \mu \mathrm{m}$. Fig. 7 reveals

20 Greater proportion of the Southern part of the study area as characterized with high AQI (AQI $\geq$

21 32) having northern part and small proportion in the southwestern part characterized with low

22 AQI. The distribution of tortuosity and AQI in the study area shows similar variation as regions

23 of high AQI are associated to high tortuosities. This suggests that AQI of an area is affected by

24 the nature of its tortuosity variation. Graph of AQI against tortuosity Fig. 8 reveals a direct 
25 polynomial relation as shown in equation 14 with a high coefficient of determination $\left(R^{2}=0.997\right)$.

26 The AQI as acclaimed by Fig. 8 and equation 14, increases as tortuosity increases in an isotropic

27 hydrogeologic unit.

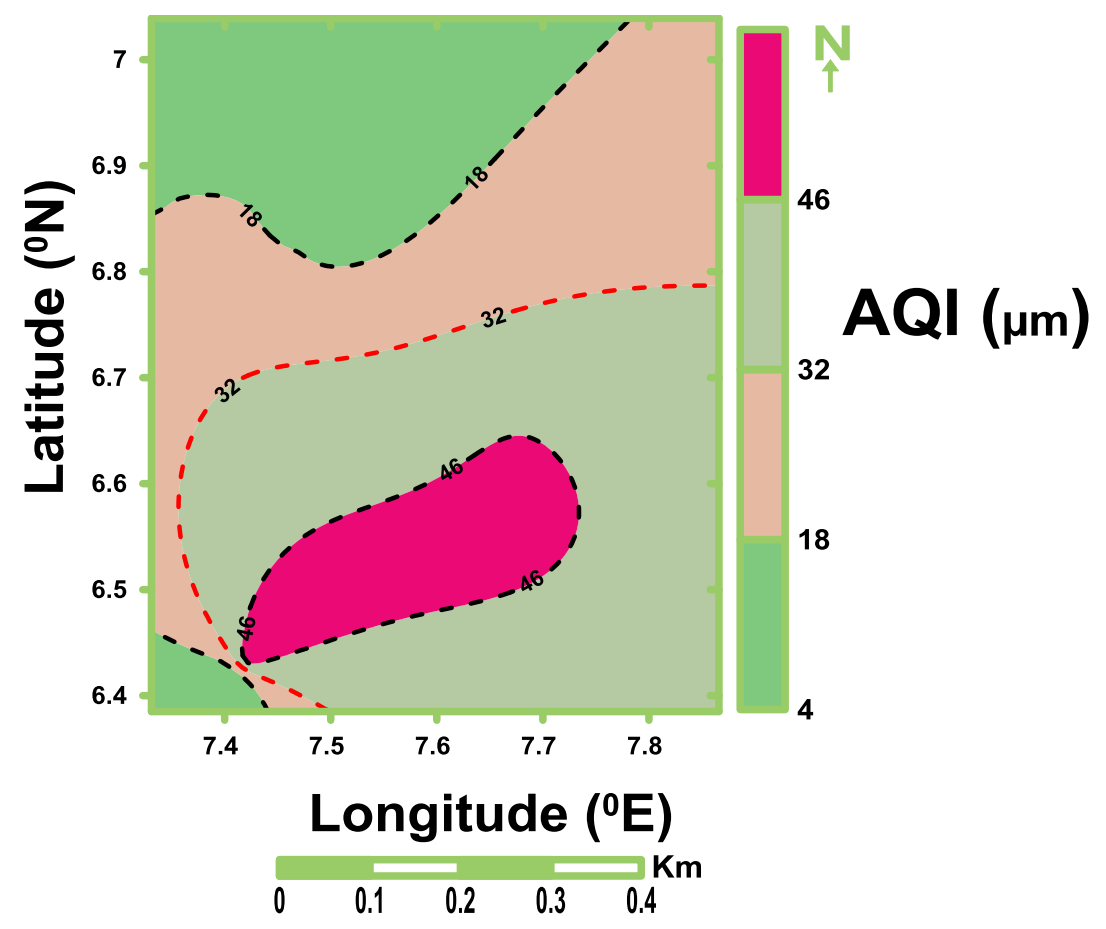

29 Fig 7: Contour map showing AQI variation

30

31

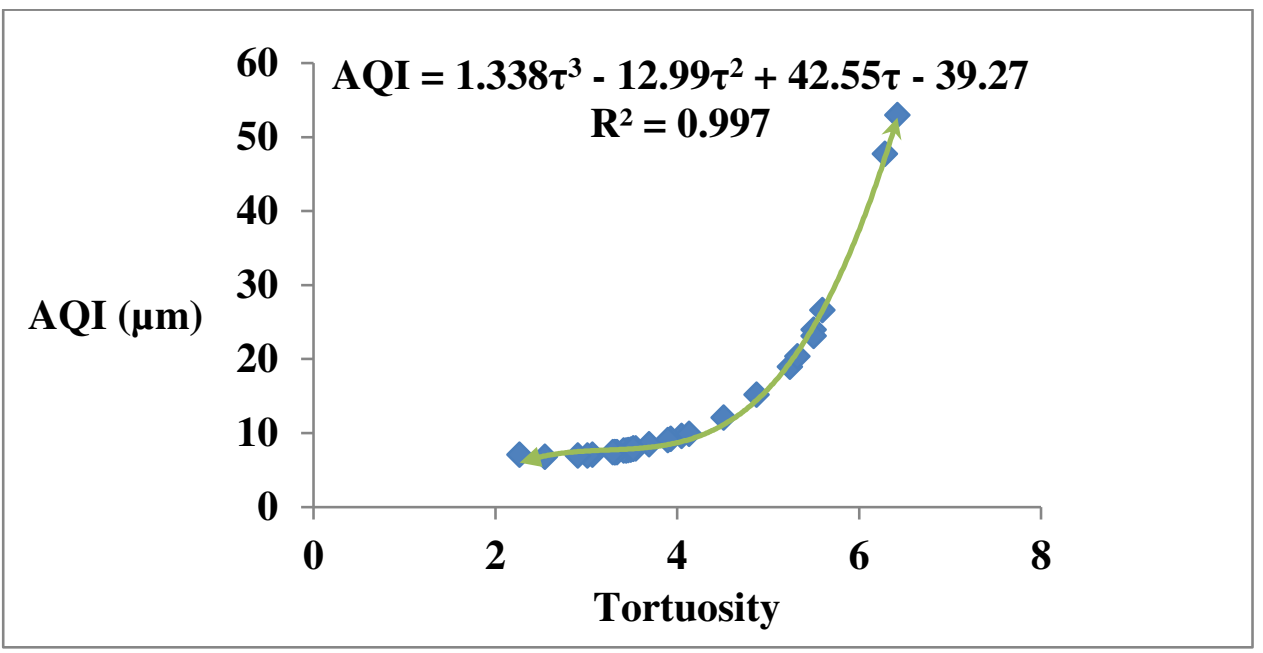

32 Fig.8: Graph of AQI against tortuosity 
33 $A Q I=1.338 \tau^{3}-12.99 \tau^{2}+42.55 \tau-39.27$

34 FZI values range from 37.582 to $1962.074 \mu \mathrm{m}$. From the value range, the study area is identified 35 to be divided into high and low flow zones. Fig. 9 shows the variation of FZI in the study area, 36 having northern and southern part of the study area characterized with low (FZI $\leq 1100)$ and high 37 (FZI $\geq 1100)$ FZI respectively with a small portion in the southwestern part characterized with 38 low FZI. From the variation, the aquifer layer in the northern part is characterized with pore 39 filing and clays as well as fine grained poorly sorted sands while the southern part is 40 characterized with coarse grained and well sorted sands (Kassab and Teama 2018).

41

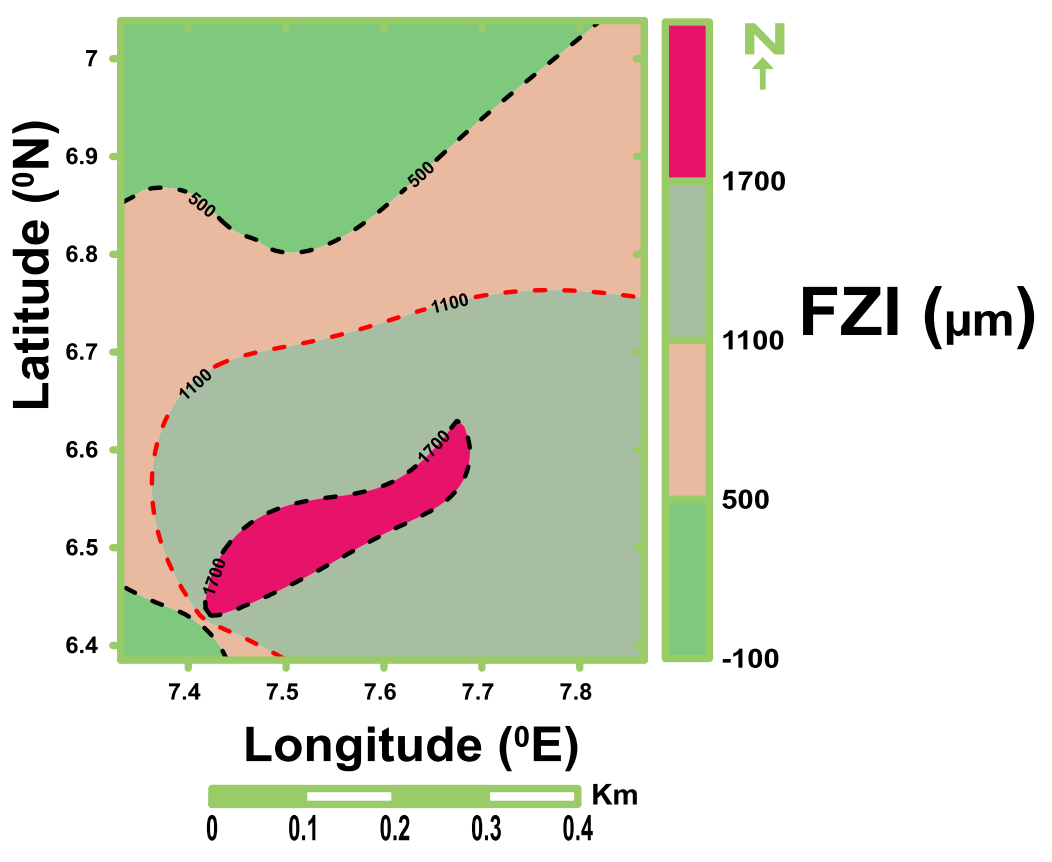

$43 \quad$ Fig. 9: Contour map showing FZI variation

44 Hydraulic flow unit variation from the contour map (Fig. 10) shows its dependency on AQI and 45 FZI as its variation reveals its similarity with AQI and FZI. The similarity in the distribution 46 shows the manifestation of the distinctiveness of the hydraulic unit in the considered parameters. 47 Table 1 shows that HFU values range from 18 to 26. Fig.10 shows Greater part of the study area 
48 as characterized with high hydraulic flow unit (HFU $\geq 23)$, with the northern part and a small 49 portion along the southwestern part characterized with low HFU (HFU $\leq 23$ ). HFU along the 50 study area is divided into nine distinct properties (18, 19, 20, 21, 22, 23, 24, 25 and 26). These 51 properties differ from one unit to another but similar in the same flow unit. This reflects the fact 52 that each unit has fluid flow properties different from other units.

53

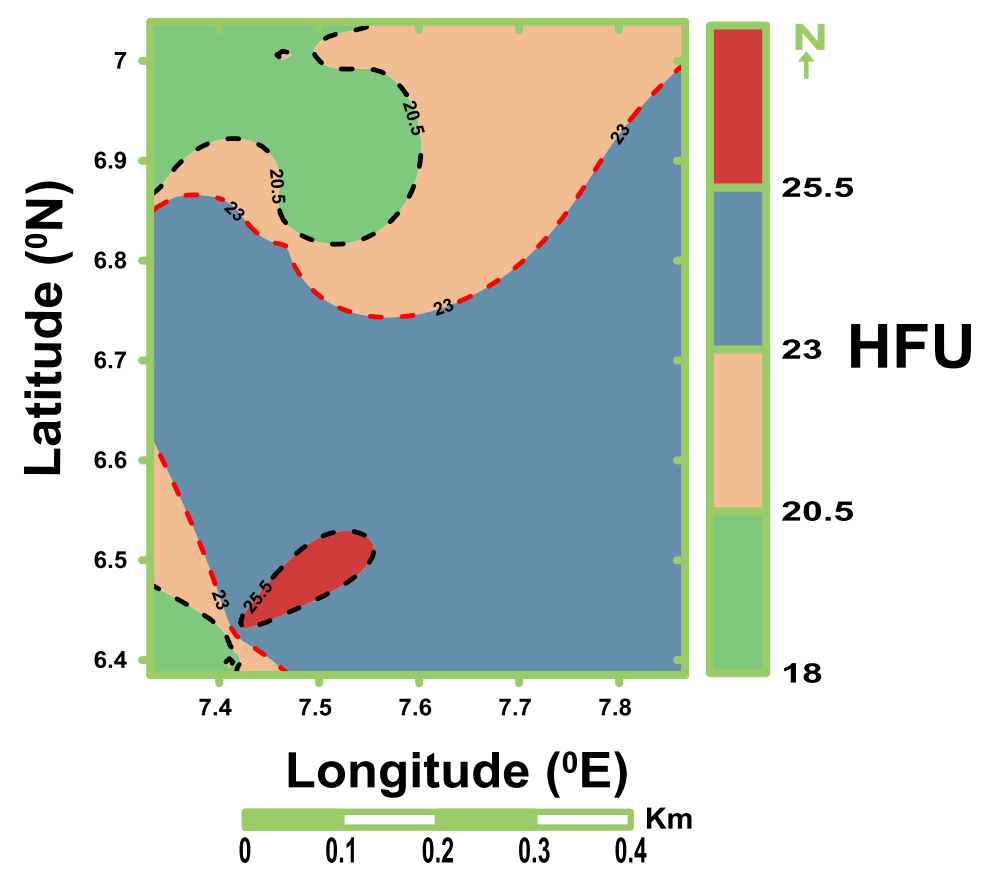

55 Fig 10: Contour map showing HFU variation

56 Fig. 11 shows classification of thirsty hydrogeologic unit on the basis of quantum geologic 57 formation also referred to as hydraulic unit. From the hydrogeologic units identified, nine 58 location shows similar hydraulic unit sticking to 20 , three locations shows hydraulic unit 59 conforming to 18,22 and 23 respectively, seven locations has HU sticking to 19, two locations 60 has HU sticking to 21 and 24, while one location each has HU conforming to 25 and 26. From 61 Fig.11 it is observed that greater number of hydrogeologic unit locations conforms to HU 20 and 62 HU 19. Following Jodeyri-Agaii et al. (2018), the reservoir quality of the nine hydraulic flow 
63 unit observed in the considered hydrogeologic unit is very high based on cut off values on flow 64 zone indicator (Log FZI > 0.25). The illustration in Fig. 11 suggests that sediment with similar

65 fluid flow should be mapped out and grouped together (Gholinezhad and Masihi 2012).

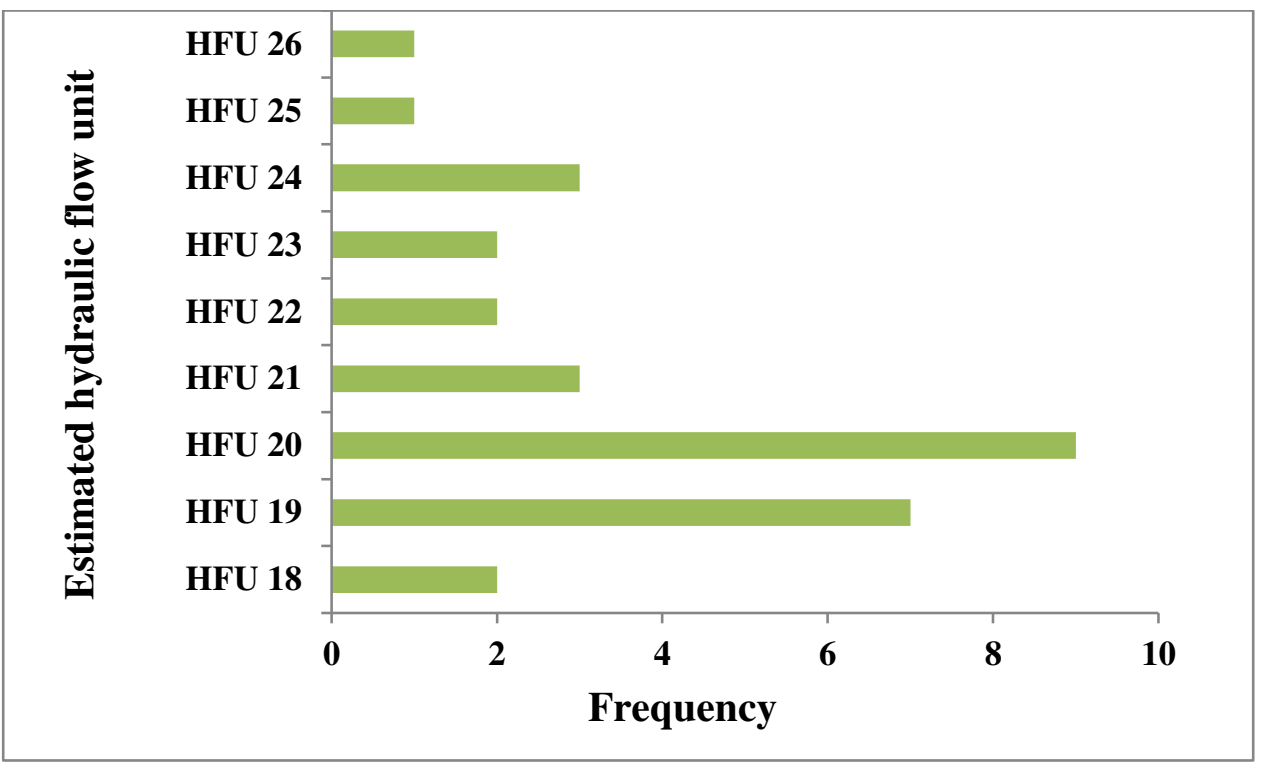

67 Fig. 11: Graph showing estimated hydraulic flow unit and its frequency.

68 The relation between HFU and FZI as shown in Fig. 12 and equation 15 reveals a proportion 69 curved line and direct relation between the two properties. The relation shows that an increasing 70 FZI will result to an increasing hydraulic flow unit within a homogenous aquifer unit. This may 71 not be applicable in a heterogeneous unit as a distinctive hydraulic unit will not uphold to the 72 FZI attributed outside its vault (George et al 2017). Formations with narrow range of flow zone 73 indicator magnitude belong to an innate hydraulic flow unit and (Prasad 2003).

74

75 


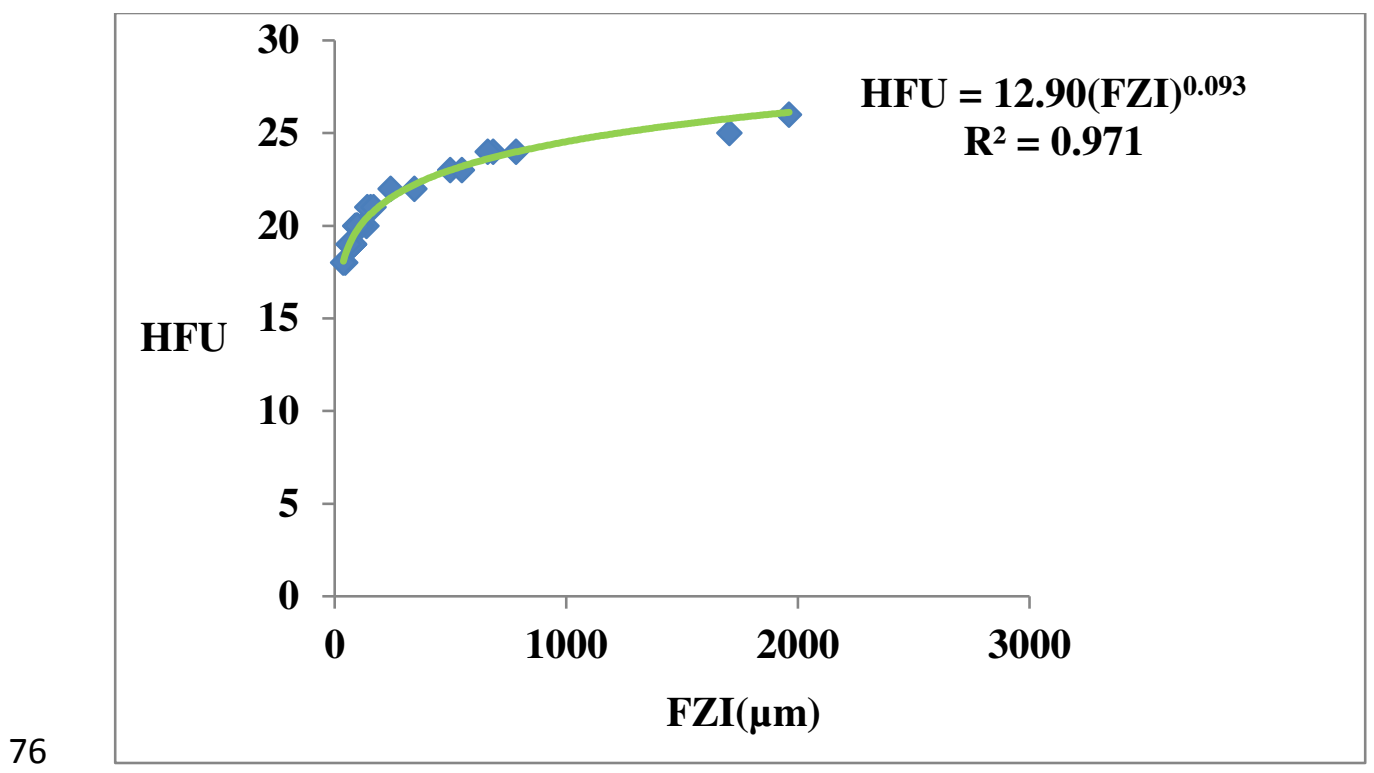

77 Fig. 12: Graph of Hydraulic flow Unit against Flow zone Indicator

$78 \quad H F U=12.90(F Z I)^{0.093}$

79

80

81

82

83

84

85

86

87

88

89

90

91 
93 Electrical resistivity result has been used to estimate the hydrokinetic properties of

94 hydrogeologic units of some parts in Enugu state. The results reveal the distribution and inter95 relationship of these properties in the considered units. The result shows that permeability of the 96 hydrogeologic unit is not wholly dependent on the unit's fractional porosity as southern parts of 97 the study area which are highly permeable are not highly porous. The result reveals the dependency of AQI on tortuosity as areas with high AQI corresponds to areas with high 99 tortuosity. Hydrokinetic properties are bona fide tool for flow unit estimation and 100 characterization of groundwater repository into their specific hydraulic unit based on quantum 101 geologic formation type. The result of the hydrokinetic properties reveals that VES stations 102 established at the southern part of the study area account for areas with high tortuosity, AQI, FZI 103 and HFU with northwestern part and a small fraction on the southwestern part characterized with 104 low tortuosity, AQI, FZI and HFU. The hydrogeologic unit of the study area was observed to be 105 classified into nine hydraulic flow units (HFU 18, HFU 19, HFU 20, HFU 21, HFU 22, HFU 23, 106 HFU 24, HFU 25 and HFU 26) with HFU 19 and HFU 20 dominating the study area. The results 107 from the nine hydraulic flow units based on flow zone indicator cut off values (Log FZI > 0.25) 108 shows that the reservoir quality is very high. The empirical relations connecting the hydrokinetic 109 properties were generated and the equations derived could be applied in modeling groundwater 110 repositories for productive characterization of groundwater into its unique hydraulic units.

\section{Acknowledgements}

112 The authors are grateful to the grateful to the atmospheric and geophysics research group in the 113 department of Physics and Astronomy, University of Nigeria, Nsukka. 


\section{Declaration of Competing Interest}

116 The authors declare no conflicts of interest

117 Availability of data materials

118 The datasets during and/or analysed during the current study available from the corresponding

119 author on reasonable request.

\section{Funding}

121 This research was funded by the authors whose names appear on the manuscript

\section{Authors' contributions}

123 All the authors contributed in the aspect of this research.

\section{References}

125 Abd-Elhamid, H. F., Javidi, A. A., 2011. A cost-effective method to control seawater intrusion in coastal aquifers. Water Resource Management, 25(11), 2755-2780.

128

129

130

131

132

133

134 135 DOI: $10.1007 / \mathrm{s} 11269-011-9837-7$

Akpan, A. E., Ugbaja, A. N., George, N. J., 2013. Integrated geophysical, geochemical and hydrogeological investigation of shallow groundwater resources in parts of the IkomMamfe Embayment and the adjoining areas in Cross River State, Nigeria. Environmental Earth Sciences, 70(3), 1435-1456. DIO: 10.1007/s12665-013-2232-3

Akpan, A.E., George, N. J., George, A. M., 2009. Geophysical investigation of some prominent gully erosion sites in Calabar, south-eastern Nigeria and its implications to hazard prevention. Disaster Adv 2(3):46-50

Akpan, F. S., Etim, O. N., Akpan, A. E., 2006. Geoelectrical investigation of groundwater potential in parts of Etim Ekpo local government area, Akwa Ibom State. Nigerian. J Phys 18:39-44 DOI:10.4314/njphy.v18i1.38080 
Amaefule, J. O., Altunbay M., Tiab, D., Kersey, D. G., Keelan, D. K., 1993. Enhanced reservoir description using core and log data to identify hydraulic (flow) and predict permeability in uncored intervals/wells. In SPE 26436, presented at 68th annual technical conference and exhibition, Houston, Texas. https://doi.org/10.2118/26436-MS

Basack, S., Bhattacharya, A. K., Maity, P., 2014. A coastal groundwater management model with Indian case study. Proceedings of the Institution of Civil Engineers: Water Management, 167(3), 126-140. https://doi.org/10.1680/wama.12.00008

Carman, P. C., 1939. Permeability of saturated sands, soils and clays. Journal of Agricultural Science, 29, 263-273. DOI: https://doi.org/10.1017/S0021859600051789

Chakravarthi, V., Shankar, G. B. K., Muralidharan, D., Harinarayana, T., Sundararajan, N. 2007. An integrated geophysical approach for imaging subbasalt sedimentary basins: case study of Jam river basin, India. Geophysics 72(6): 141-147. https://doi.org/10.1190/1.2777004

George, N. J., 2020. Appraisal of Hydraulic Flow Units and Factors of the Dynamics and Contamination of Hydrogeological Units in the Littoral Zones: A Case Study of Akwa Ibom State University and Its Environs, Mkpat Enin L.G.A, Nigeria. Journal of the International Association for Mathematical Geosciences. DOI 10.1007/s11053-02009673-9

George, N. J., Ibuot, J. C., Ekanem, A. M., George, A. M., 2018. Estimating the indices of intertransmissibility magnitude of active surficial hydrogeologic units in Itu, Akwa Ibom State, southern Nigeria. Arabian Journal of Geoscience. 11:1-16 DOI 10.1007/s12517018-3475-9

George, N. J., Ekanem, A. M., Ibanga, J. I., Udosen, N. I., 2017. Hydrodynamic 
Implications of Aquifer Quality Index (AQI) and Flow Zone Indicator (FZI) in groundwater abstraction: A case study of coastal hydro-lithofacies in South-eastern Nigeria. Journal of Coastal Conservation. https://doi.org/10.1007/s11852-017-0535-3.

George, N. J., Akpan, A. E., Ekanem, A. M., 2016. Assessment of textural variational pattern and electrical conduction of economic and accessible quaternary hydrolithofacies via geoelectric and laboratory methods in SE Nigeria: A case study of select locations in Akwa Ibom State. Journal of Geological Society of India, 88(4), 517-528. $10.1007 / \mathrm{s} 12594-016-0514-6$

Gholinezhad, S., Masihi, M., 2012. A physical-based model of permeability/porosity relationship for the rock data of Iran Southern Carbonate Reservoirs. Iranian Journal of Oil and Gas Science and Technology, 1(1), 25-36. 10.22050/IJOGST.2012.2772

Heigold, P. C., Gilkeson, R. H., Cartwright, K., Reed, P. C., 1979. Aquifer TransmissivityFrom Surficial Electrical Methods. Groundwater, 17(4): 338345. doi.org/10.1111/j.1745-6584.1979.tb03326.x

Jodeyri-Agaii H. R., Rahimpour-Bonab, V., Tavakoli1, R., Kadkhodaie-Ilkhchi M. R., Yousefpour 2018. Integrated approach for zonation of a mid Cenomanian carbonate reservoir in a sequence stratigraphic framework Geologica Acta, 16(3): 321-337. DOI: 10.1344/GeologicaActa2018.16.3.5. DOI:https://doi.org/10.1344/GeologicalActa2018.16.3.5

Kassab, M. A., Teama, M. A., 2018. Hydraulic flow unit and facies analysis integrated study for reservoir characterisation: a case study of Middle Jurassic rocks at Khashm El-Galala, Gulf of Suez, Egypt Arabian Journal of Geosciences 11:294. https://doi.org/10.1007/s12517-018-3595-2 
Kozeny, J., 1927. Ueber kapillare leitung des wassers im boden: Sitzungsberichte der.

Akademie der Wissenschaften in Wien,136, 271-306.

Ofomata, G. E. K. 1967. Some Observations on Relief and Erosion in Eastern Nigeria. Revue deGeomorph, Dynamise. XVU, pp. 21-29.

Porras, J.C., Campos, O., 2001. Rock typing: a key approach for petrophysical characterization and definition of flow units, Santa Barbara Field, Eastern Venezuela Basin. Society of Petroleum Engineers. (SPE), Buenos Aires (Argentina), Latin American and Caribbean Petroleum Engineering Conference, 25-28 March, 6pp. DOI: https://doi.org/10.2118/69458-MS

Prasad, M., 2003. Velocity-permeability relations within hydraulic units. Geophysics, 68, 108117. DOI: https://doi.org/10.1190/1.1543198

Rao, S. V. N., Sreenivasulu, V., 2004. Planning groundwater development in coastal aquifers. Hydrological Science, 49(1), 155-170. https://doi.org/10.1623/hysj.49.1.155.53999

Schlager, W., 2005. Carbonate sedimentology and sequence stratigraphy. SEPM, Concepts in Sedimentology and Paleontology, Series 8, 200 pp.

DOI: https://doi.org/10.2110/csp.05.08

Stow, D. A. V., 2005. Sedimentary rocks in the field: A colour guide. Mason Publ. Ltd. London. 320.

The Netherland Organisation 1976. Geophysical well logging for geohydrological purposes in unconsolidated Formations. Groundwater Survey TNO. The Netherlands Organisation for Applied Scientific Research, Delft. OCLC no: 68104428 
208

209

210

211

212

213

214

215

216

217

218

219

220 
Figures

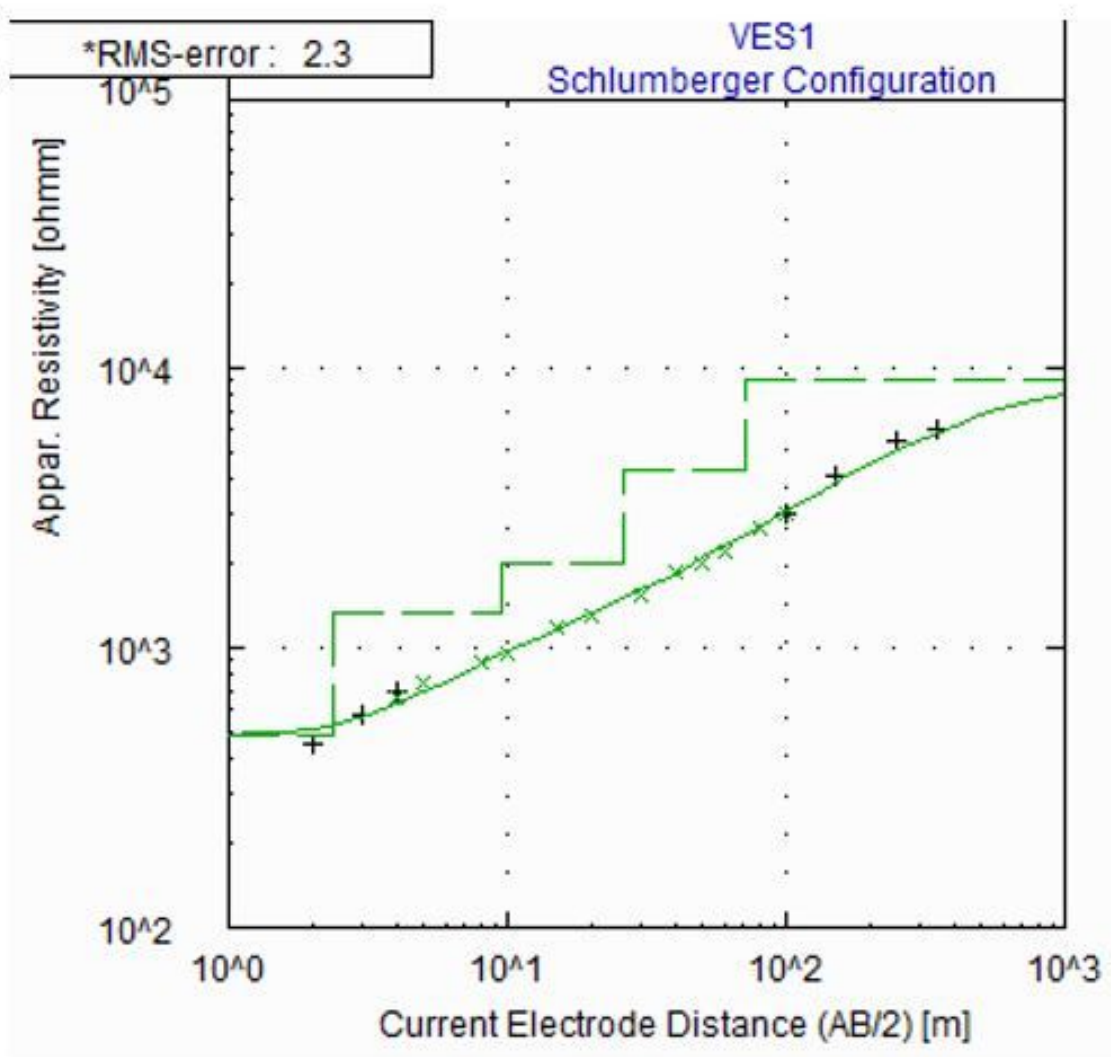

\begin{tabular}{|lccc|} 
No & Res & Thick & Depth \\
\hline 1 & 487.0 & 2.4 & 2.4 \\
2 & 1338.3 & 7.1 & 9.5 \\
3 & 2022.6 & 16.3 & 25.8 \\
4 & 4354.9 & 45.9 & 71.7 \\
5 & 8994.5 & -- & -- \\
* & & & \\
RMS on smoothed data
\end{tabular}

Figure 1

VES curve showing VES1 resistivity, thickness and Depth 


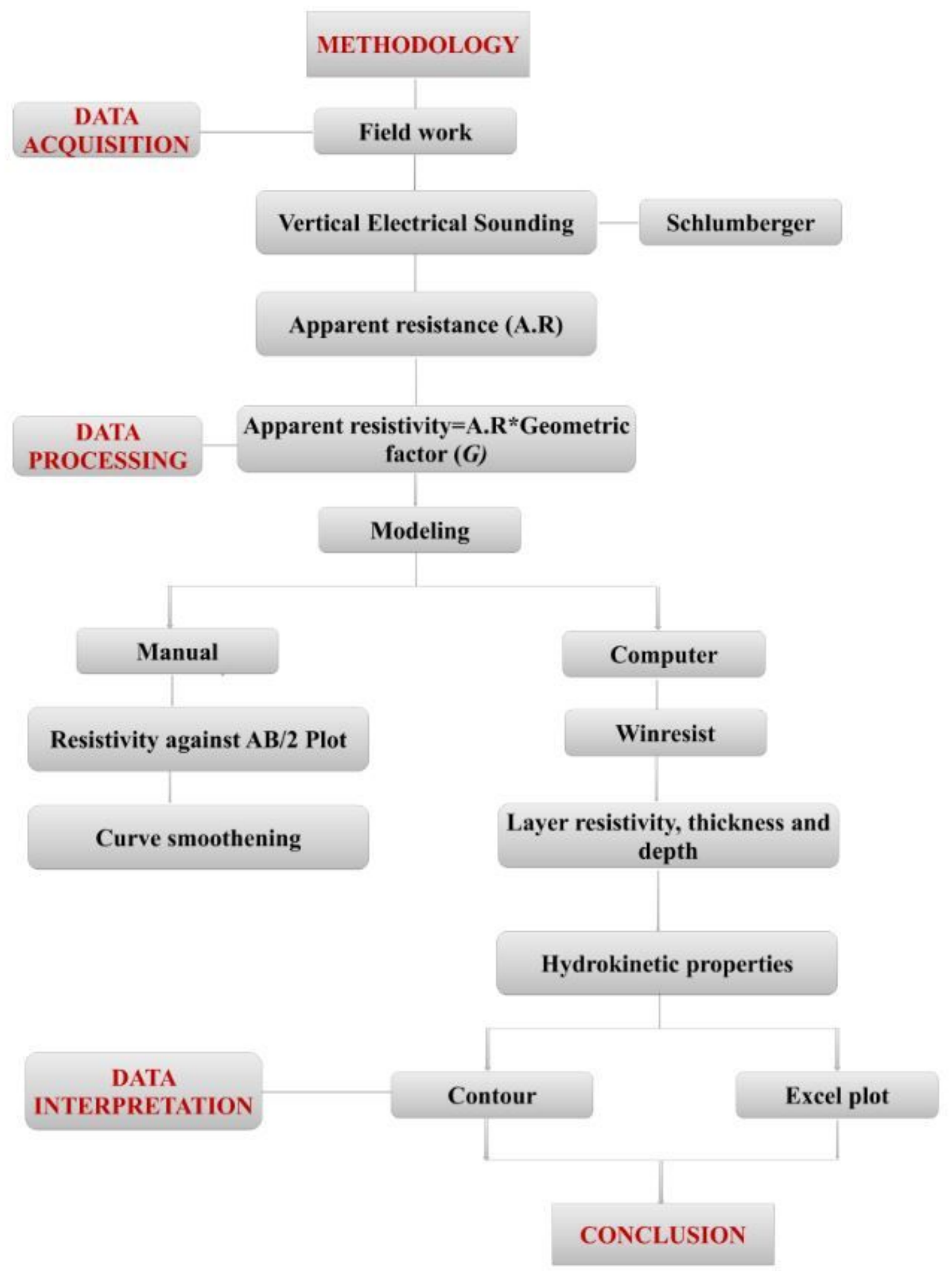

Figure 2

Flow chart showing research methodology 


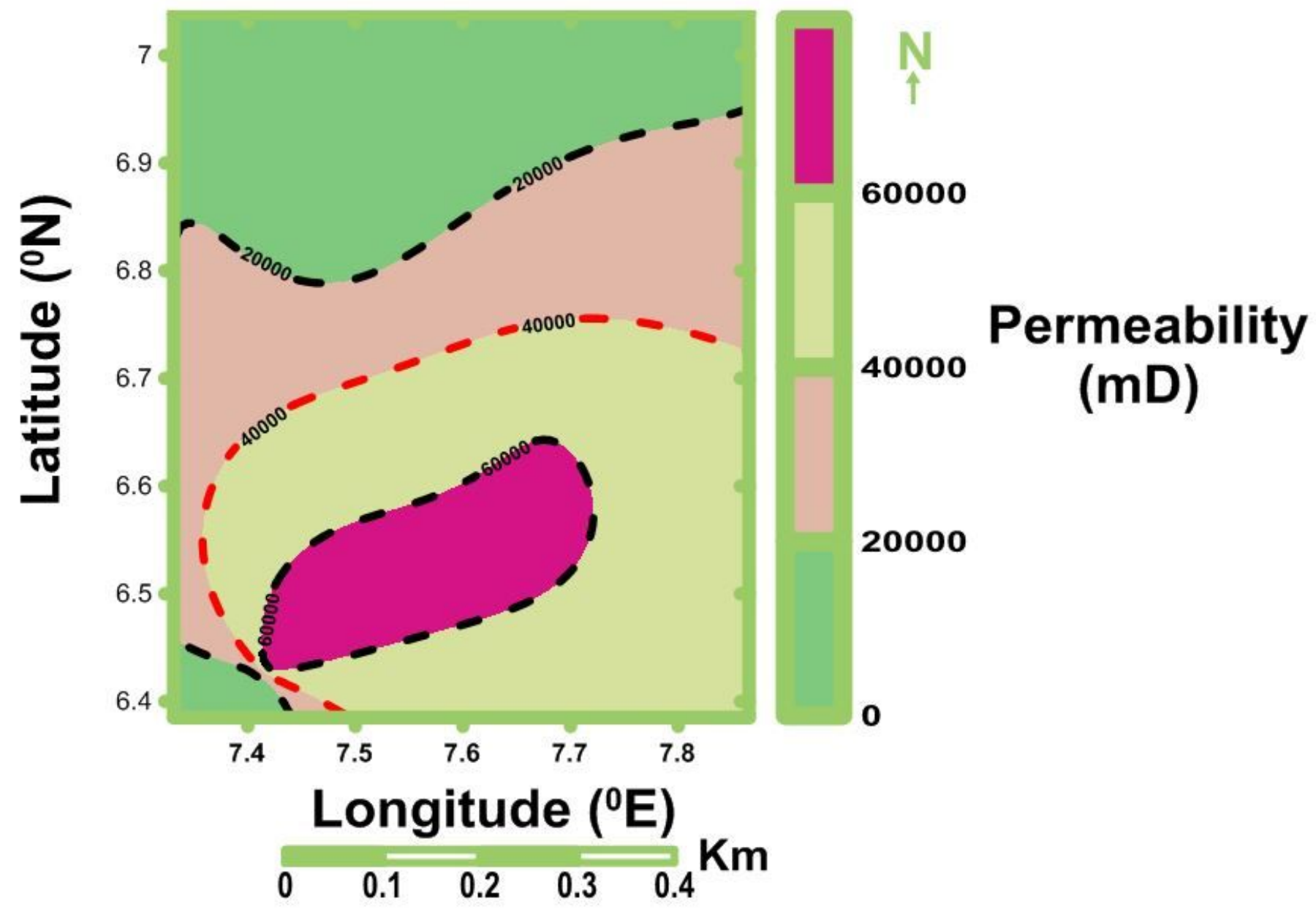

Figure 3

Contour map showing Permeability variation 

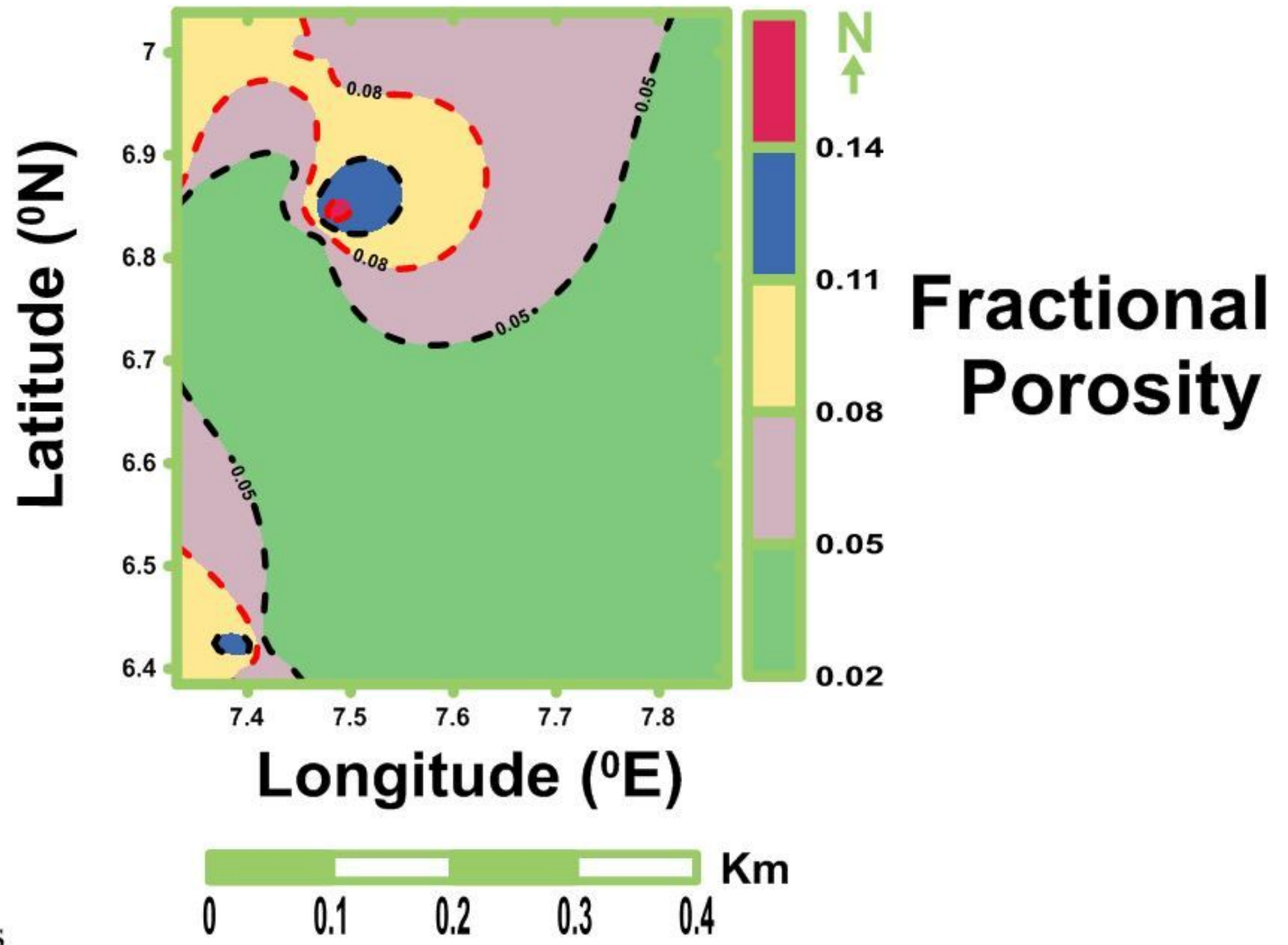

Figure 4

Contour map showing Fractional porosity variation 


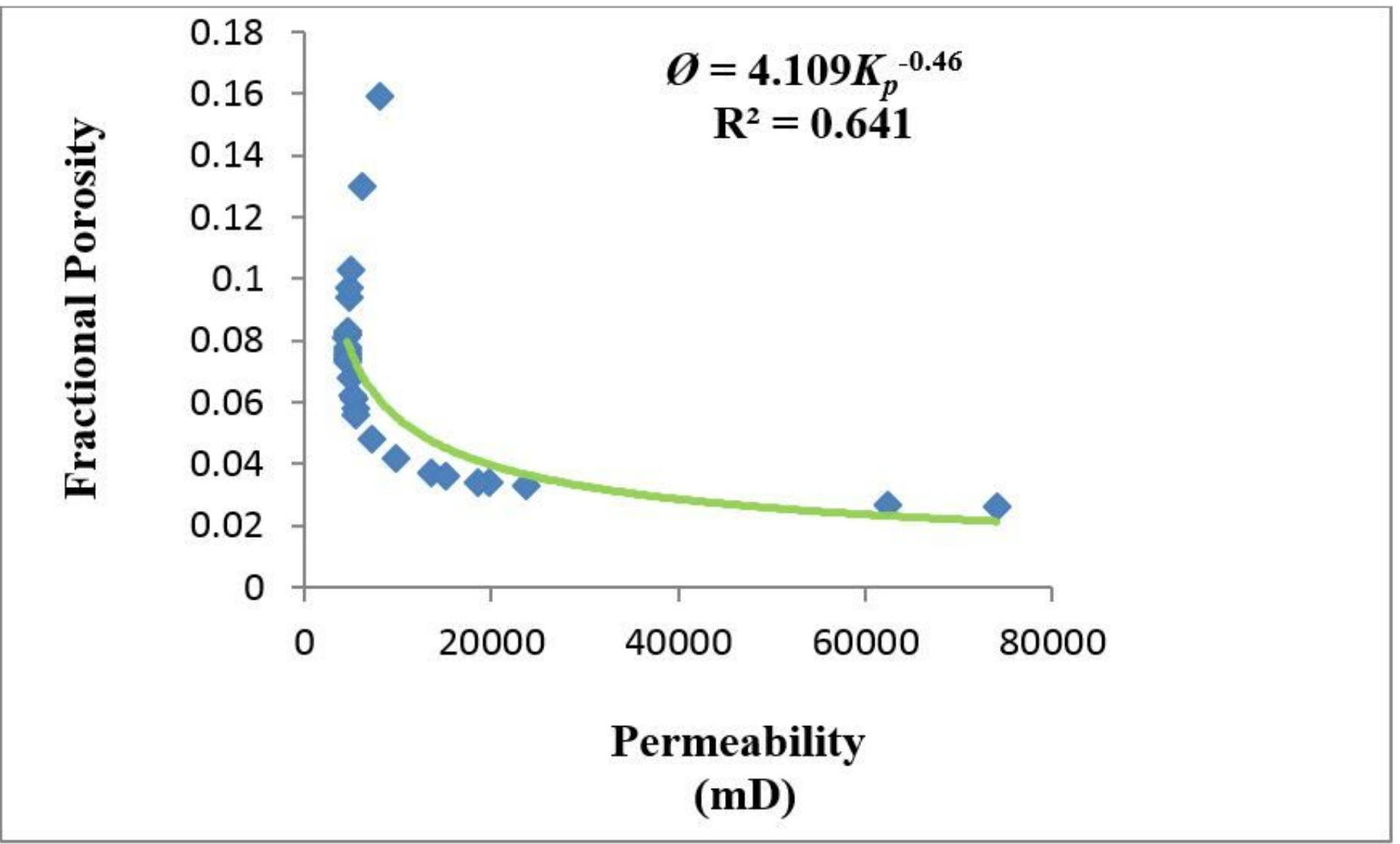

Figure 5

Graph of porosity against permeability 


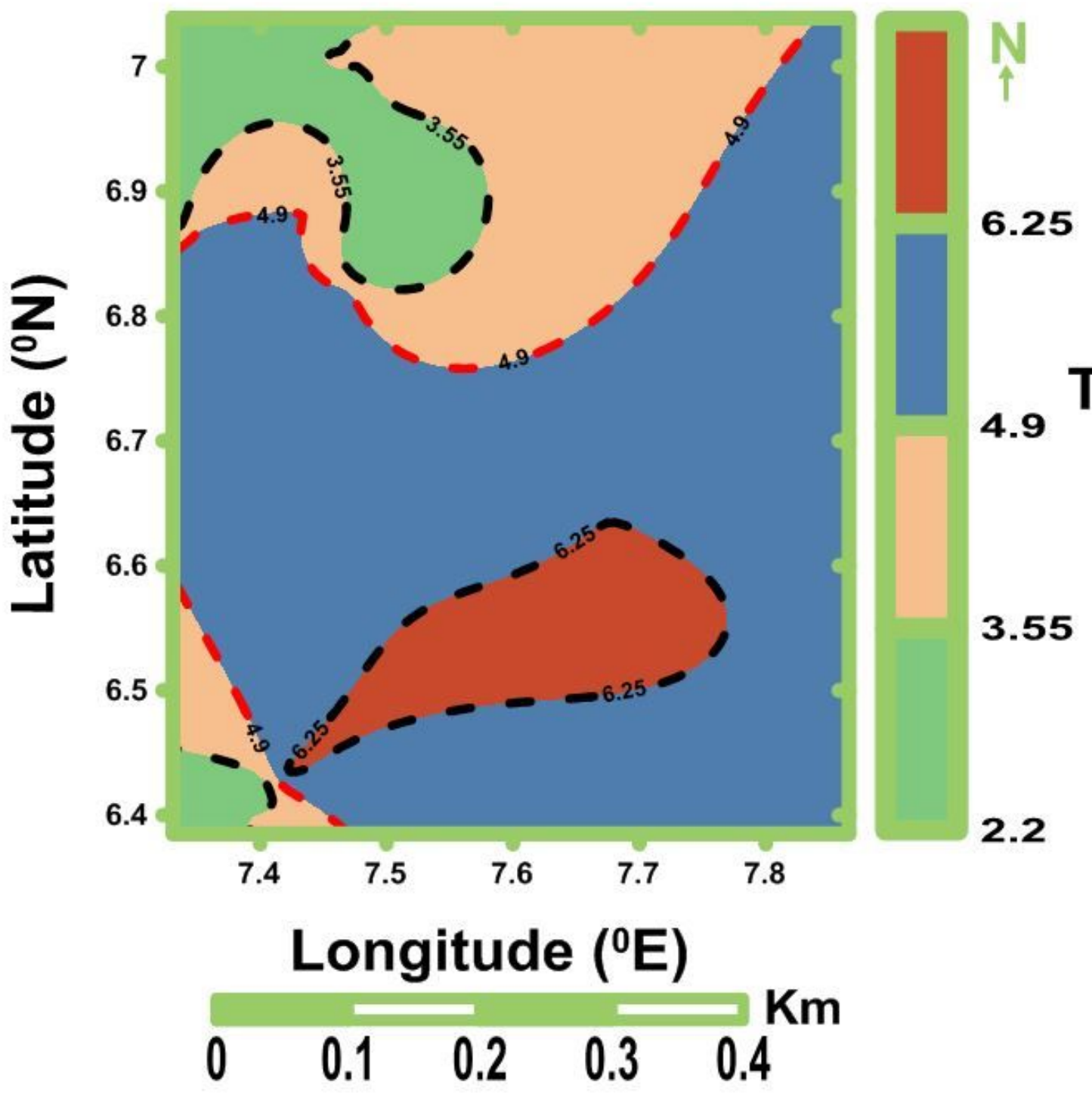

Figure 6

Contour map showing Tortuosity variation 


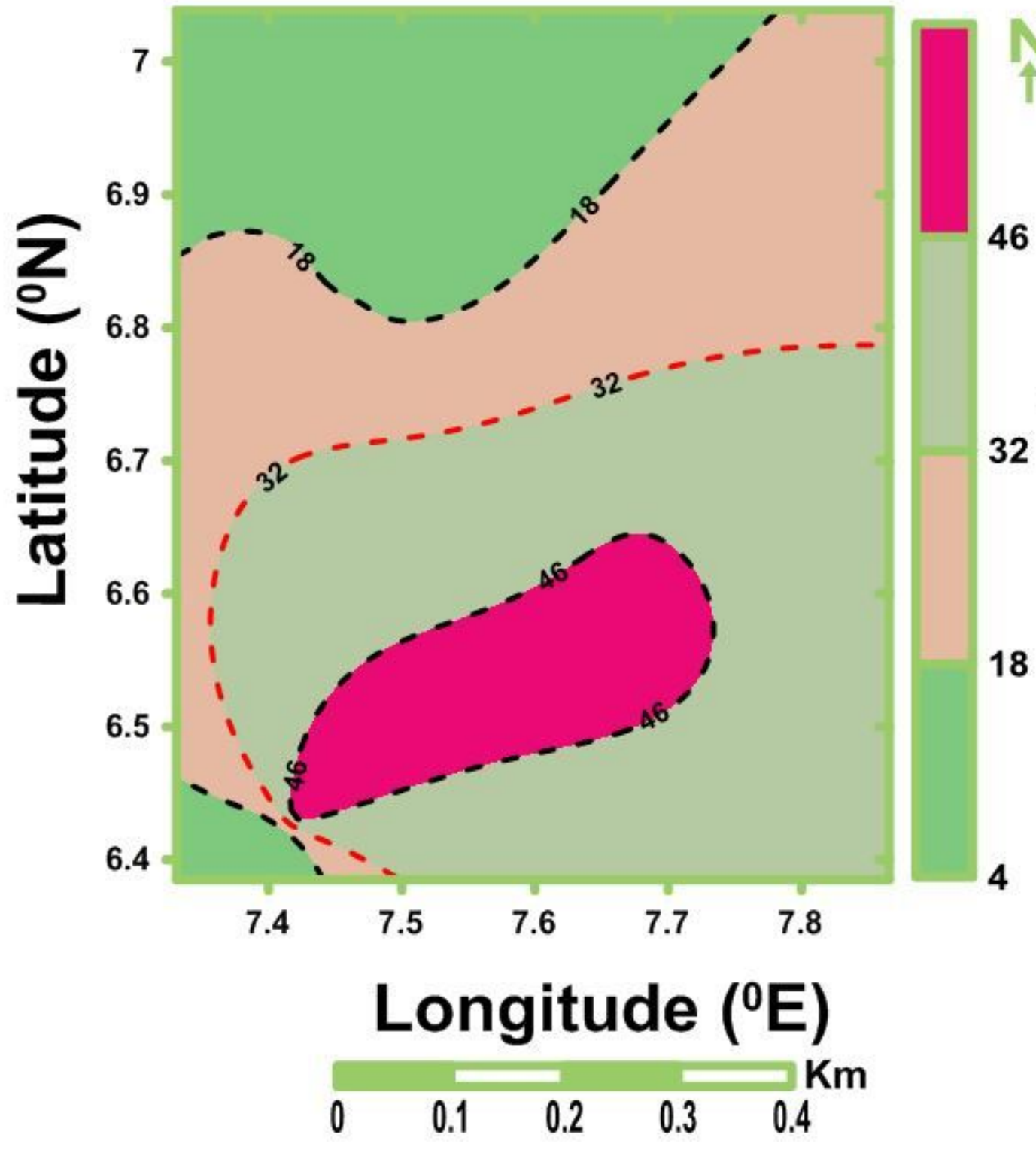

Figure 7

Contour map showing AQI variation 


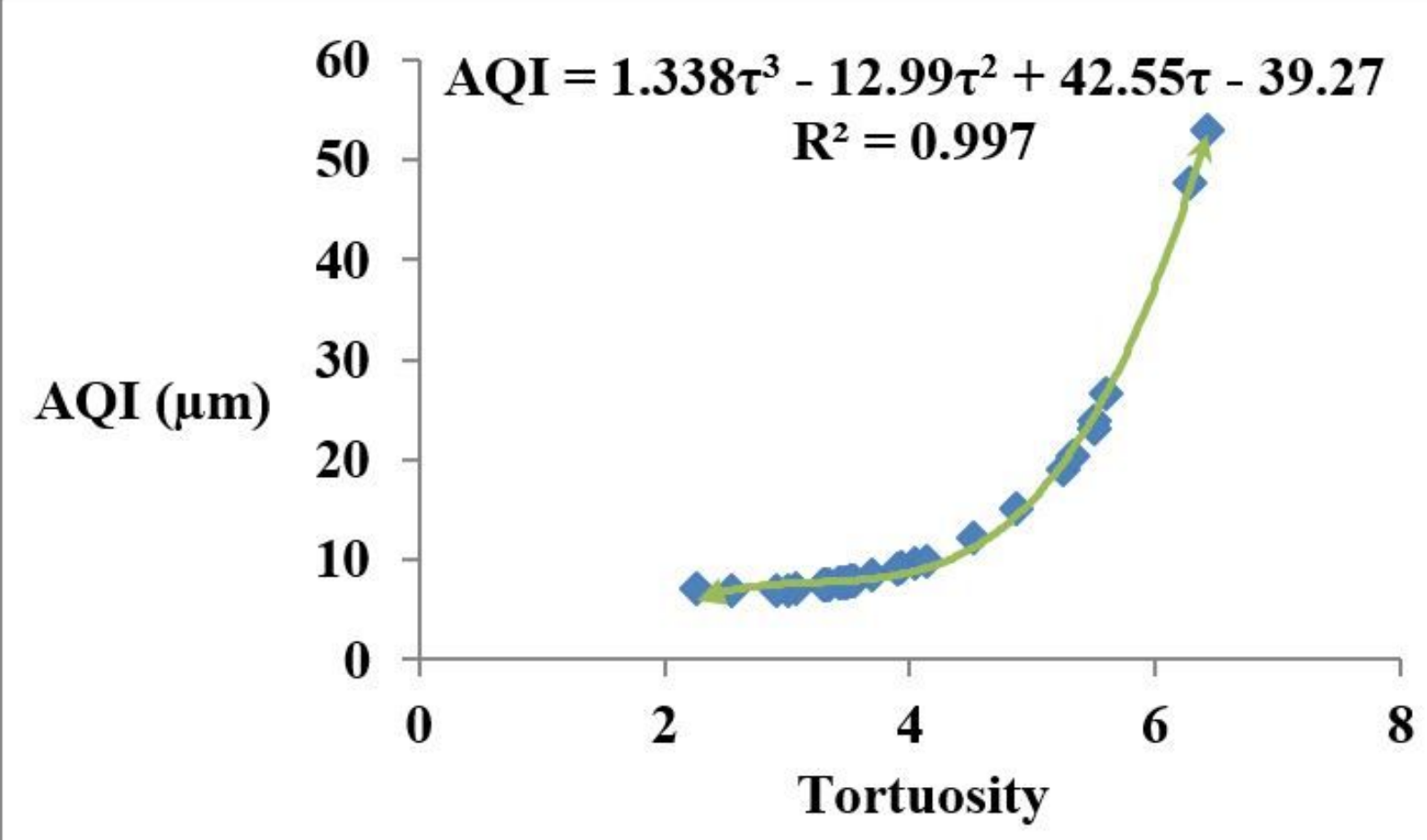

Figure 8

Graph of AQI against tortuosity 


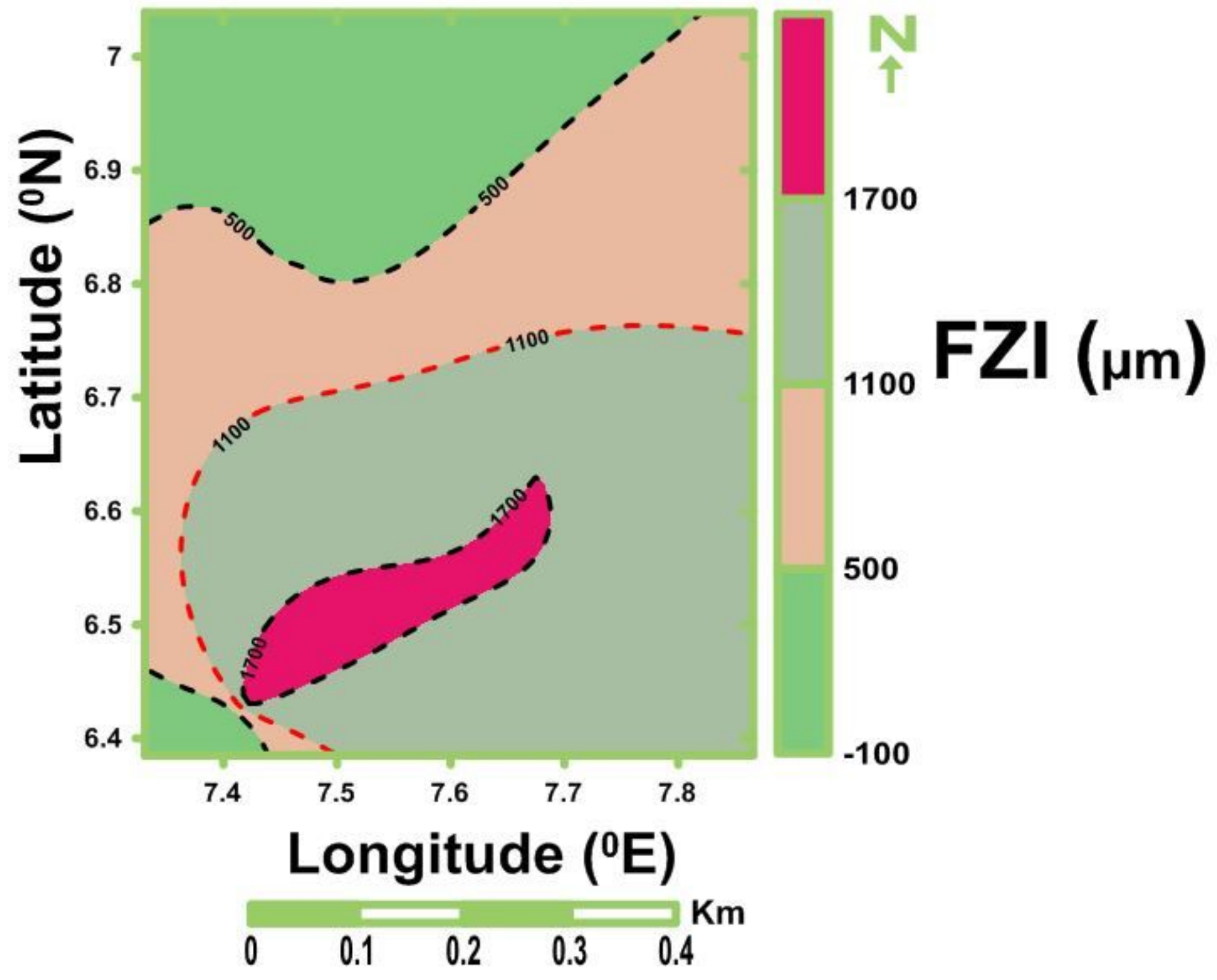

Figure 9

Contour map showing FZI variation 


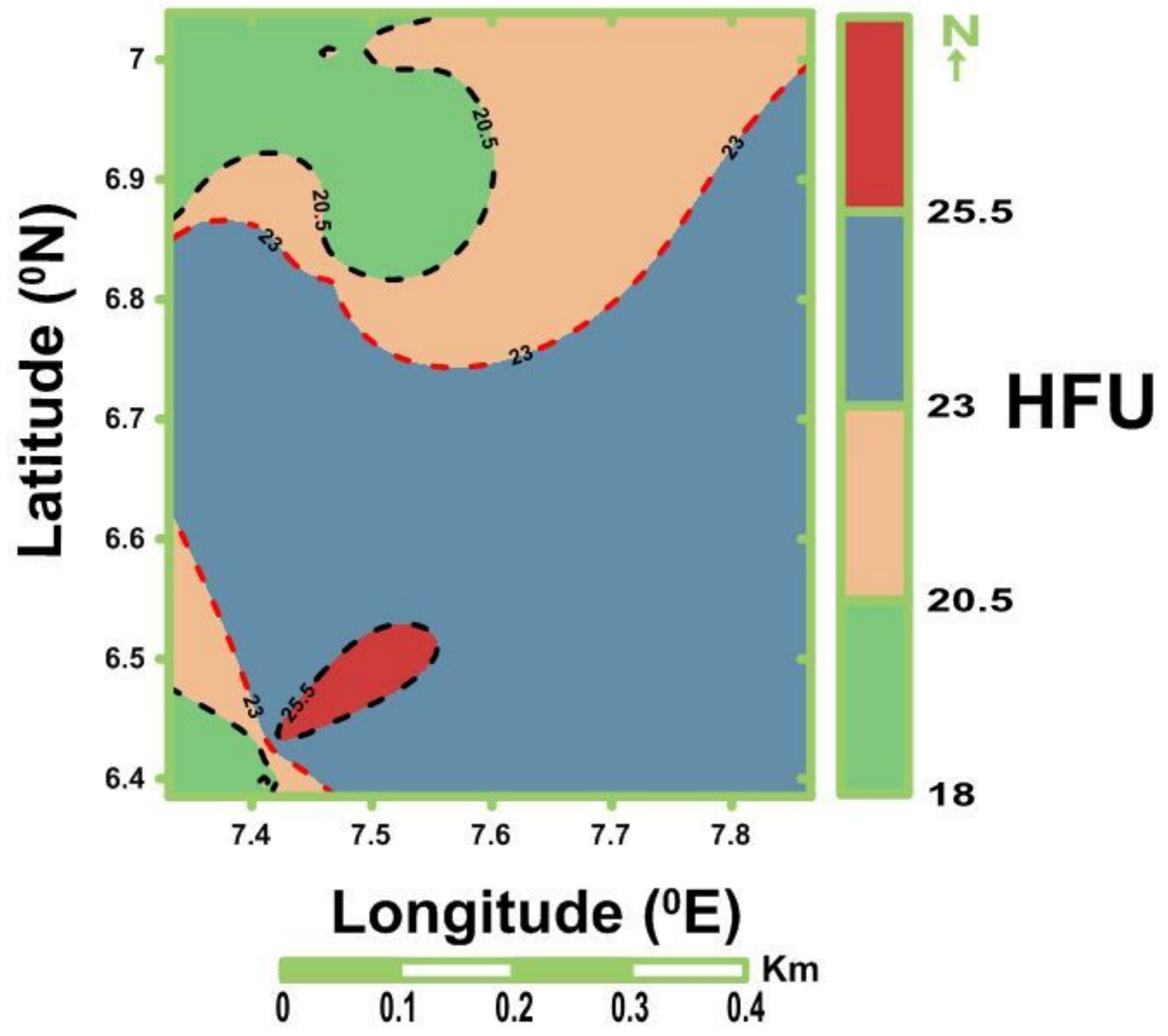

Figure 10

Contour map showing HFU variation 


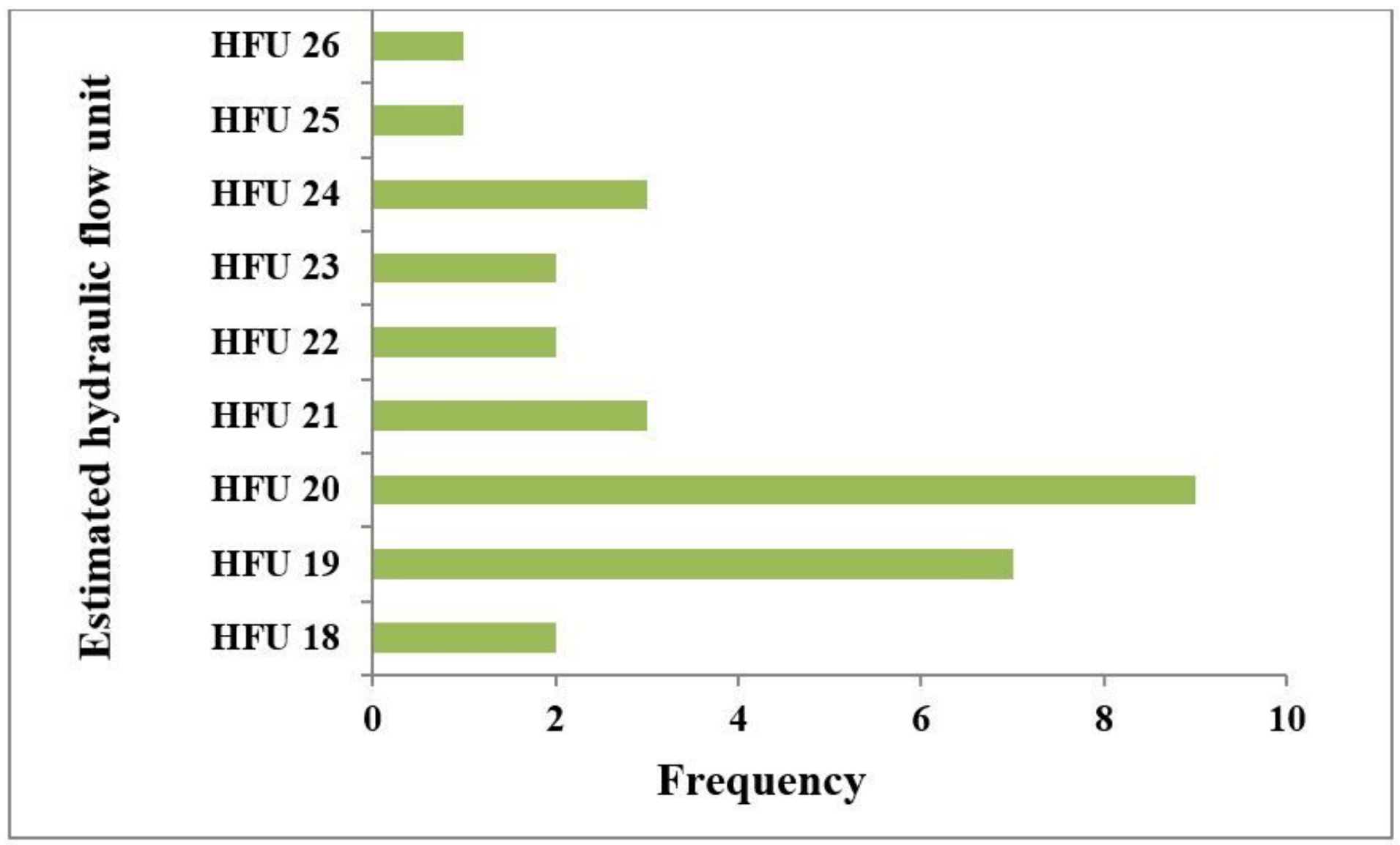

Figure 11

Graph showing estimated hydraulic flow unit and its frequency. 


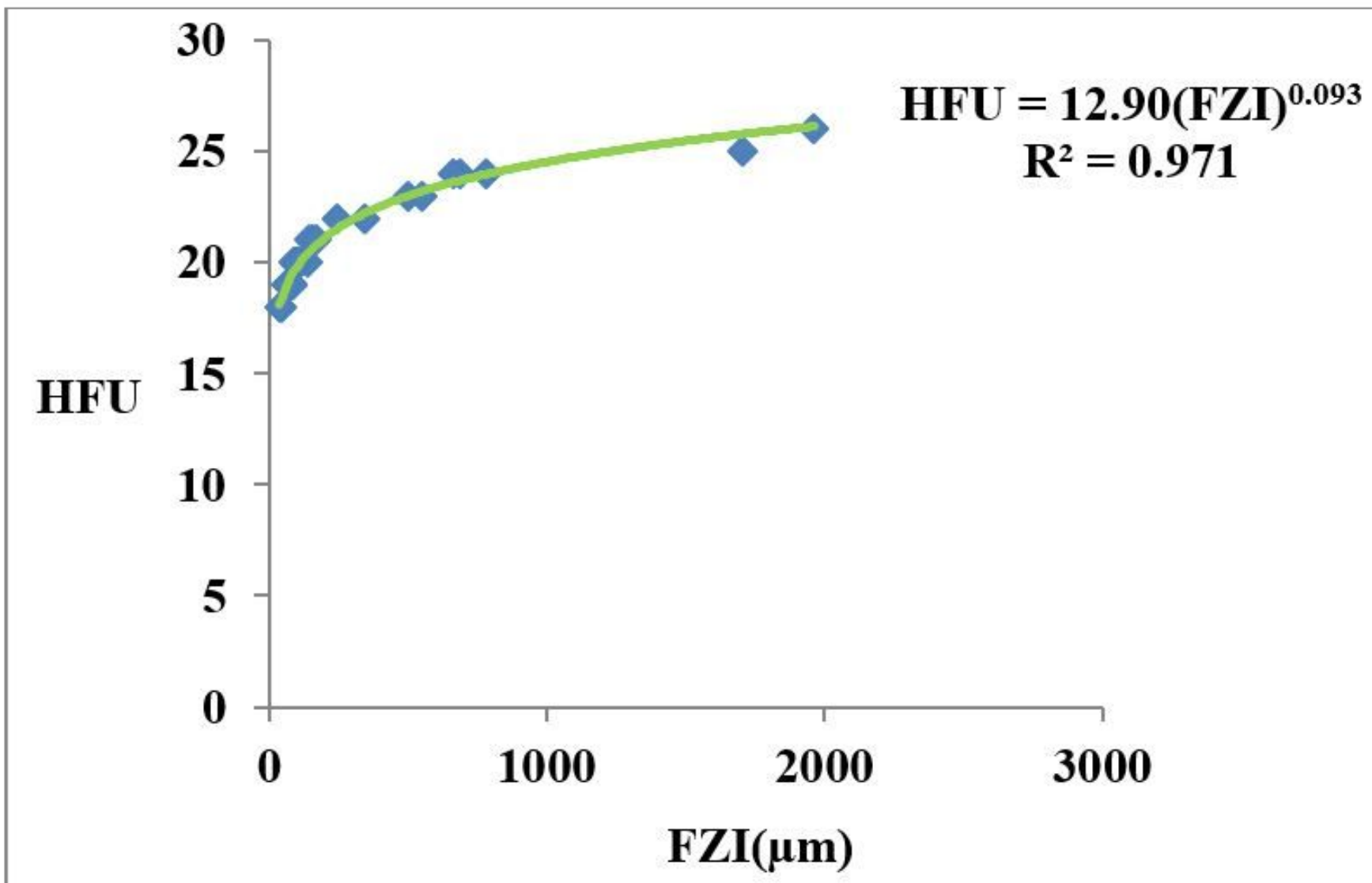

Figure 12

Graph of Hydraulic flow Unit against Flow zone Indicator 